\title{
GEOLOGICAL SURVEY OF CANADA RADIOCARBON DATES V
}

W. DYCK, J. A. LOWDON, J. G. FYLES, and W. BLAKE, JR.*

Geological Survey of Canada, Ottawa, Canada

\section{INTRODUCTION}

Both the 2-L counter, described in GSC I, and the 5-L counter (GSC IV) were operated routinely during the past year. Approximately onehalf of the determinations reported here were obtained from each counter. The 5-L counter was operated mainly at $1 \mathrm{~atm}$.

For more than a year, age calculations have been carried out monthly by an I.B.M. 1620 computer. If the background, standard, and sample counts during a month conform to statistical laws, they are entered on sheets together with their respective counting times and sample identifications and sent to the computing center for processing.

The calculations are based on a $\mathrm{C}^{14}$ half-life of $5568 \pm 30 \mathrm{yr}$ and 0.95 of the activity of the NBS oxalic-acid standard, and the ages are quoted in years before 1950. The age errors include: counting errors of sample, background, and standard; the error in the half-life of $\mathrm{C}^{14}$; and an error term to account for the average variation of $\pm 1.5 \%$ in the $\mathrm{C}^{14}$ concentration of the biosphere during the past $1100 \mathrm{yr}$. "Infinite" ages are based on the $4 \sigma$ criterion (GSC II).

No changes have been made in the routine sample-preparation and purification techniques described in GSC IV.

For the interest of other laboratories, the average background and standard counting rates over the past 14 months are listed in Tables 1 and 2 , respectively. The monthly average background count is made up of 4 individual daily counts. During the 14 month period ten different background preparations were counted in each counter, and no count was rejected. The standard counting rates listed in Table 2 are the monthly averages of 3 individual daily counts. Again none of the oxalic-acid standard preparations (10 for each counter) and none of the daily counts were rejected.

In order to gain further information on the validity of $\mathrm{C}^{14}$ dates from bones, several samples were separated into the organic (collagen) and inorganic (carbonate) fractions using the first procedure described by Berger et al. (1964). The results are shown in Table 3. As expected, the carbonate fraction is younger than the collagen except for GSC-488, where good agreement between the ages of whale ear bone collagen and carbonate possibly suggests that dates of carbonates from closed bone structure are more reliable than dates from open bone structure. Note the excellent agreement between jaw bone collagen (GSC-447) and tooth dentin (GSC-490) from a bison jaw bone in which the teeth were still

* The introductory part of this paper has been prepared by the first two authors; the latter now operates the laboratory. The date list has been compiled by the third and fourth authors from descriptions of samples and interpretations of dates by various collectors. 
TABLE 1

Monthly Background (c/m) for Period

August 1, 1964 to October 1, 1965

\begin{tabular}{lcr}
\hline \multicolumn{1}{c}{ Month } & $\begin{array}{c}2-\mathrm{L} \text { counter } \\
(2 \mathrm{~atm})\end{array}$ & $\begin{array}{c}5-\mathrm{L} \text { counter } \\
(1 \mathrm{~atm})\end{array}$ \\
\cline { 2 - 3 } & $1.254 \pm .017$ & $2.306 \pm .029$ \\
August 1964 & $1.218 \pm .013$ & $2.366 \pm .028$ \\
September & $1.253 \pm .021$ & $* 3.119 \pm .020$ \\
October & $1.279 \pm .016$ & $2.362 \pm .017$ \\
November & $1.240 \pm .014$ & $2.352 \pm .019$ \\
December & $1.300 \pm .018$ & $2.399 \pm .018$ \\
January 1965 & $1.263 \pm .018$ & $2.399 \pm .025$ \\
February & $1.209 \pm .017$ & $2.350 \pm .024$ \\
March & $1.240 \pm .019$ & $* 3.093 \pm .026$ \\
April & $1.244 \pm .019$ & $2.280 \pm .026$ \\
May & $1.240 \pm .027$ & $2.305 \pm .038$ \\
June & $1.209 \pm .035$ & $2.318 \pm .038$ \\
July & $1.239 \pm .017$ & $2.301 \pm .038$ \\
August & $1.238 \pm .018$ & $2.268 \pm .024$ \\
September & & \\
\hline
\end{tabular}

* 5-L counter operating at $4 \mathrm{~atm}$.

in place. In the other 2 cases where comparison of different sample types was possible (GSC-450 and GSC-150; GSC-454 and L604A, L604B, Lamont VII) there is also excellent agreement between the bone collagen and the associated shell material. Sample GSG-454 is rather unique in that the carbonate fraction dates "modern" whereas the collagen date is $10,420 \mathrm{yr}$.

TABLE 2

Monthly Standard, $\mathrm{N}_{\mathrm{o}}{ }^{*},(\mathrm{c} / \mathrm{m})$ for Period August 1, 1964 to October 1, 1965

\begin{tabular}{|c|c|c|}
\hline Month & $\begin{array}{l}2-\mathrm{L} \text { counter } \\
(2 \mathrm{~atm})\end{array}$ & $\begin{array}{l}\text { 5-L counter } \\
(1 \mathrm{~atm})\end{array}$ \\
\hline August 1964 & 20.087 士.069 & $28.536 \pm .118$ \\
\hline September & $19.965 \pm .067$ & $28.451 \pm .085$ \\
\hline October & $19.922 \pm .069$ & $* * 111.003 \pm .219$ \\
\hline November & $19.931 \pm .070$ & $28.429 \pm .114$ \\
\hline December & $20.059 \pm .066$ & $28.630 \pm .157$ \\
\hline January 1965 & $19.763 \pm .098$ & $28.752 \pm .116$ \\
\hline February & $20.008 \pm .095$ & $28.504 \pm .115$ \\
\hline March & $20.137 \pm .077$ & $29.032 \pm .114$ \\
\hline April & $20.003 \pm .105$ & $* * 110.624 \pm .231$ \\
\hline May & $19.974 \pm .097$ & $28.705 \pm .130$ \\
\hline June & $19.971 \pm .101$ & $28.820 \pm .124$ \\
\hline July & $20.044 \pm .150$ & $28.774 \pm .117$ \\
\hline August & $20.112 \pm .096$ & $28.790 \pm .120$ \\
\hline September & $19.986 \pm .094$ & $28.940 \pm .114$ \\
\hline
\end{tabular}

* $\mathrm{N}_{\mathrm{o}}=0.95 \mathrm{X}$ net counting rate of the NBS oxalic-acid standard.

** 5-L counter operating at 4 atm. 
Column 4 of Table 3 lists the fractional counting rates expressed in percent with respect to the corrected oxalic-acid standard. The counting error of the standard is not included in the error of the fractions (GSC IV).

TABLE 3

Comparison of Organic and Inorganic Fractions of Bones*

\begin{tabular}{|c|c|c|c|}
\hline Sample No. & Fraction & Age (yr) & $\begin{array}{l}\text { Net counting rate } \\
(\% \text { of standard })\end{array}$ \\
\hline GSC-266 & $\begin{array}{c}\text { Whale rib } \\
\text { Collagen } \\
\text { Carbonate }\end{array}$ & $\begin{array}{l}8640 \pm 140 \\
3260 \pm 130\end{array}$ & $\begin{array}{l}34.09 \pm 0.22 \\
66.57 \pm 0.30\end{array}$ \\
\hline $\begin{array}{l}\text { GSC- } 355 * * \\
\text { GSC-488** }\end{array}$ & $\begin{array}{l}\text { Whale baleen } \\
\text { Whale ear (bone) } \\
\text { Collagen } \\
\text { Carbonate } \\
\text { Whale limb } \\
\text { Collagen } \\
\text { Carbonate }\end{array}$ & $\begin{array}{l}1110 \pm 130 \\
980 \pm 140 \\
840 \pm 130 \\
930 \pm 130 \\
480 \pm 140\end{array}$ & $\begin{array}{l}87.06 \pm 0.29 \\
88.53 \pm 0.50 \\
90.08 \pm 0.43 \\
89.06 \pm 0.28 \\
94.14 \pm 0.58\end{array}$ \\
\hline GSC-361 & $\begin{array}{c}\text { Whale vertebra } \\
\text { Collagen } \\
\text { Carbonate }\end{array}$ & $\begin{array}{l}3050 \pm 130 \\
2310 \pm 150\end{array}$ & $\begin{array}{l}68.40 \pm 0.36 \\
75.00 \pm 0.72 \\
\end{array}$ \\
\hline GSC-362 & $\begin{array}{c}\text { Whale jaw } \\
\text { Collagen } \\
\text { Carbonate }\end{array}$ & $\begin{array}{l}2820 \pm 130 \\
2220 \pm 130\end{array}$ & $\begin{array}{l}70.36 \pm 0.33 \\
75.80 \pm 0.33\end{array}$ \\
\hline GSC-447 & $\begin{array}{l}\text { Bison jaw } \\
\text { Collagen } \\
\text { Carbonate }\end{array}$ & $\begin{array}{l}6160 \pm 140 \\
1090 \pm 140\end{array}$ & $\begin{array}{l}46.48 \pm 0.27 \\
87.28 \pm 0.47\end{array}$ \\
\hline GSC- $490 * * *$ & $\begin{array}{l}\text { Bison teeth } \\
\text { Dentin } \\
\text { Carbonate }\end{array}$ & $\begin{array}{l}6100 \pm 180 \\
2130 \pm 130\end{array}$ & $\begin{array}{l}46.80 \pm 0.70 \\
76.72 \pm 0.35\end{array}$ \\
\hline GSC-449 & $\begin{array}{l}\text { Charred bone } \\
\text { Organic } \\
\text { Carbonate }\end{array}$ & $\begin{array}{r}1160 \pm 120 \\
390 \pm 130\end{array}$ & $\begin{array}{l}86.50 \pm 0.29 \\
95.25 \pm 0.50 \\
\end{array}$ \\
\hline GSC-150 & $\begin{array}{l}\text { Whale vertebra } \\
\text { Collagen } \\
\text { Carbonate } \\
\text { Shells }\end{array}$ & $\begin{array}{l}8990 \pm 140 \\
4990 \pm 140 \\
9180 \pm 170\end{array}$ & $\begin{array}{l}32.66 \pm 0.20 \\
53.75 \pm 0.28 \\
31.90 \pm 0.13\end{array}$ \\
\hline GSC-452 & $\begin{array}{c}\text { Whale bone } \\
\text { Collagen } \\
\text { Carbonate }\end{array}$ & $\begin{array}{r}1380 \pm 130 \\
450 \pm 130\end{array}$ & $\begin{array}{l}84.24 \pm 0.48 \\
94.51 \pm 0.50 \\
\end{array}$ \\
\hline $\begin{array}{l}\text { L604A } \\
\text { L604B }\end{array}$ & $\begin{array}{l}\text { Whale bone (beluga) } \\
\text { Collagen } \\
\text { Carbonate } \\
\text { Shells } \\
\text { Shells }\end{array}$ & $\begin{array}{l}10,420 \pm 150 \\
\text { Modern } \\
10,700 \pm 200 \\
10,550 \pm 200\end{array}$ & $\begin{array}{r}27.33 \pm 0.14 \\
105.00 \pm 0.65\end{array}$ \\
\hline
\end{tabular}

* Detailed descriptions of all samples appear in this date list except for GSC-150 (GSC III) and L604A, L604B (Lamont VII), and GSC-361, 362, 447, 490 and 452, deferred to a later list.

** These three samples are all from the same whale.

*** Teeth from jaw (GSC-447). 
Tests for $\mathrm{C}^{14}$ contamination in shell samples (cf. GSC II, GSC III, and GSC IV) were continued during the past year as shown in Part A of Table 4.

Further tests were carried out on the problem of humic contamination of peat samples from permafrost areas (GSC IV). The results are listed in Part B of Table 4, and again show that contamination is absent. This conclusion is strengthened by the analyses of the completely untreated portions of GSC-305 and GSC-310.

\section{ACKNOWLEDGMENTS}

Thanks are extended to Ian M. Robertson for assistance in the preparation and measurement of samples in the laboratory. The second author would like to express thanks to W. Dyck for his invaluable instruction on the intricacies of $\mathrm{C}^{14}$ dating.

TABLE 4

Tests for $\mathrm{C}^{14}$ contamination*

\begin{tabular}{|c|c|c|c|}
\hline Sample No. & Fraction & $\begin{array}{c}\text { Age } \\
(\mathrm{yr} \text { B.P.) }\end{array}$ & $\begin{array}{l}\text { Net counting rate } \\
(\% \text { of standard })\end{array}$ \\
\hline \multicolumn{4}{|c|}{ A. Marine Shells } \\
\hline GSC-277 & $\begin{array}{l}23-59 \% \\
60-100\end{array}$ & $\begin{array}{l}>47,400 \\
>49,000\end{array}$ & $\begin{array}{l}0.132 \pm 0.037 \\
0.117 \pm 0.025\end{array}$ \\
\hline GSC-350 & $\begin{array}{l}44-72 \\
73-100\end{array}$ & $\begin{array}{l}7860 \pm 150 \\
7980 \pm 150\end{array}$ & $\begin{array}{ll}37.57 & \pm 0.32 \\
36.97 & \pm 0.29\end{array}$ \\
\hline GSC-351 & $\begin{array}{l}49-74 \\
75-100\end{array}$ & $\begin{array}{l}5910 \pm 140 \\
6010 \pm 140\end{array}$ & $\begin{array}{l}47.86 \pm 0.26 \\
47.27 \pm 0.26\end{array}$ \\
\hline GSC-394 & $\begin{array}{c}0-50 \\
51-100\end{array}$ & $\begin{array}{l}>32,000 \\
>33,000\end{array}$ & $\begin{array}{l}0.173 \pm 0.360 \\
0.354 \pm 0.466\end{array}$ \\
\hline \multicolumn{4}{|c|}{ FrEsh Water SHELLS } \\
\hline GSC-413 & $\begin{array}{l}10-55 \\
56-100\end{array}$ & $\begin{array}{l}>35,500 \\
>34,400\end{array}$ & $\begin{array}{l}0.249 \pm 0.234 \\
0.579 \pm 0.197\end{array}$ \\
\hline \multicolumn{4}{|l|}{ B. Peat Samples } \\
\hline GSC- 300 & $\begin{array}{l}\text { less soluble** } \\
\text { more “" }\end{array}$ & $\begin{array}{l}2330 \pm 150 \\
2210 \pm 130\end{array}$ & $\begin{array}{l}74.80 \pm 0.68 \\
75.95 \pm 0.37\end{array}$ \\
\hline GSC-305 & $\begin{array}{l}\text { less soluble*** } \\
\text { more “" } \\
\text { untreated }\end{array}$ & $\begin{array}{l}220 \pm 130 \\
270 \pm 130 \\
270 \pm 130\end{array}$ & $\begin{array}{l}97.25 \\
96.73 \\
\pm 0.48 \\
96.70 \pm 0.42 \\
\pm 0.37\end{array}$ \\
\hline GSC-310 & $\begin{array}{l}\text { less soluble } \\
\text { more “" } \\
\text { untreated }\end{array}$ & $\begin{array}{l}9620 \pm 150 \\
9510 \pm 150 \\
9620 \pm 140\end{array}$ & $\begin{array}{l}30.18 \pm 0.23 \\
30.61 \\
30.18 \pm 0.23 \\
\pm 0.17\end{array}$ \\
\hline GSC-402 & $\begin{array}{l}\text { less soluble } \\
\text { more " }\end{array}$ & $\begin{array}{l}1050 \pm 140 \\
1170 \pm 140\end{array}$ & $\begin{array}{l}87.71 \pm 0.43 \\
86.42 \pm 0.66\end{array}$ \\
\hline GSC-427 & $\begin{array}{l}\text { less soluble } \\
\text { more "“ }\end{array}$ & $\begin{array}{l}>40,700 \\
>35,000\end{array}$ & $\begin{array}{l}0.059 \pm 0.16 \\
0.109 \pm 0.32\end{array}$ \\
\hline
\end{tabular}

* Detailed descriptions of all samples appear in this date list except for GSC-350, 351, 394,402 , and 427.

** Degree of solubility refers to solubility in $2 \% \mathrm{NaOH}$.

*** This sample from northern Ontario, south of zone of discontinuous permafrost. 


\section{SAMPLE DESCRIPTIONS}

I. GEOLOGIC SAMPLES

\section{A. Eastern Canada}

GSC-370. Hillsborough, Cape Breton Island

Wood from basal part of 0 to $4 \mathrm{ft}$-thick peat bed at base of $5 \mathrm{ft}$ of clayey strata with carbonaceous and vegetal layers, in road cut at head of Mabou Inlet, W of Hillsborough, Cape Breton Island, Nova Scotia $\left(46^{\circ} 04^{\prime} 30^{\prime \prime} \mathrm{N}\right.$ Lat, $61^{\circ} 17^{\prime} \mathrm{W}$ Long), at alt $<50 \mathrm{ft}$. Peat overlies oxidized sand and gravel; section is capped by red clay till. Coll. 1964 by V. K. Prest*. Comment (V.K.P.) : pollen study by R. J. Mott indicates a northern boreal forest cover rather than that of the region today. Deposits were earlier dated at $>21,000$ yr (Y-232; Flint and Rubin, 1955) and $>38,000 \mathrm{yr}$ (W-157, USGS II). Date based on one 3-day count in 5 - $\mathrm{L}$ counter at $4 \mathrm{~atm}$.

\section{GSC-290. Whycocomagh, Cape Breton Island}

Wood from $1 \mathrm{ft}$-thick plant detrital layer in 4 to $5 \mathrm{ft}$ silt and gravel unit beneath $10 \mathrm{ft}$ gravelly till in road cut on $\mathrm{N}$ side of Whycocomagh, Cape Breton Island, Nova Scotia $\left(45^{\circ} 58^{\prime} 30^{\prime \prime} \mathrm{N}\right.$ Lat, $61^{\circ} 07^{\prime} 30^{\prime \prime} \mathrm{W}$ Long). Silt-gravel unit is underlain by stony clay till on bedrock. Site first reported by D. G. Kelley in 1955. Coll. 1964 by V. K. Prest. Comment (V.K.P.) : pollen studies by R. J. Mott suggest possible correlation with Hillsborough organic deposits (GSC-370, this list). Date based on one 3-day count.

\section{GSC-283. Bay St. Lawrence, Cape Breton Island}

Wood from 1 to 5 in.-thick organic detrital layer, 20 to $30 \mathrm{ft}$ above base of $150 \mathrm{ft}$ sea cliff, SW shore of Bay St. Lawrence, Cape Breton Island, Nova Scotia $\left(47^{\circ} 00^{\prime} 50^{\prime \prime} \mathrm{N}\right.$ Lat, $60^{\circ} 27^{\prime} \mathrm{W}$ Long). Organic layer is underlain by discontinuous silt and gravel (up to 44 in. thick) on this stony till on bedrock, and overlain by thin silt passing upward through sand into gravel. Site discovered by E. R. W. Neale in 1954 (cf. Neale, 1964) . E. H. Muller (Syracuse Univ., Syracuse, New York) observed a 12 ft-thick lens of clayey sediment containing fragments of marine shells, above the upper gravels. Whole section overlain by 30 to $90 \mathrm{ft}$ of gravelly boulder till (?). Coll. 1964 by V. K. Prest. Comment (V.K.P. and R. J. Mott) : dated layer has yielded an arboreal pollen assemblage dominated by alder, with subsidiary amounts of birch and varied conifers. Deposit is inferred to represent an early Wisconsin nonglacial interval.

\section{GSC-281. Cabot Trail, Cape Breton Island}

Wood (root) from basal peat at 44 to 48 in. depth in bog on highlands, at mileage 13 from W coast, Cabot Trail, Cape Breton Island,

* All persons referred to as collectors or submitters of samples or cited as sources of data are with the Geological Survey of Canada unless otherwise specified. 
Nova Scotia $\left(46^{\circ} 45^{\prime} 30^{\prime \prime} \mathrm{N}\right.$ Lat, $60^{\circ} 5 \mathrm{1}^{\prime} \mathrm{W}$ Long). Peat overlies 20 in. of mixed cobbles, sand, and plant detritus on stony till. Coll. 1964 by V. K. Prest.

GSC-336. ' 'Salmon River Lake,' Cape Breton Island

$8770 \pm 150$

Lake mud from 3.60 to $3.80 \mathrm{~m}$ depth in core coll. with piston sampler from 'Salmon River Lake,' Richmond County, Cape Breton Island, Nova Scotia ( $45^{\circ} 38^{\prime} 40^{\prime \prime} \mathrm{N}$ Lat, $60^{\circ} 46^{\prime} 30^{\prime \prime} \mathrm{W}$ Long), at alt ca. $140 \mathrm{ft}$. Sample is from $\mathrm{B}$ (high pine) zone of the pollen profile. Coll. 1955 by D. A. and B. G. R. Livingstone, Duke Univ., Durham, North Carolina; subm. by J. Terasmae. Comment (D.A.L.): date is first from Nova Scotia on B zone in pollen sequence (cf. Flint and Deevey, 1957; Deevey, 1958; Livingstone and Livingstone, 1958). NaOH-leach omitted from sample pretreatment.

\section{GSC-335. Wreck Cove, Cape Breton Island}

$9030 \pm 170$

Lake mud from 3.10 to $3.30 \mathrm{~m}$ depth in core coll. with piston sampler from unnamed pond 13/4 mi SW of Wreck Cove, Victoria County, Cape Breton Island, Nova Scotia $\left(46^{\circ} 32^{\prime} 25^{\prime \prime} \mathrm{N}\right.$ Lat, $60^{\circ} 26^{\prime} 50^{\prime \prime} \mathrm{W}$ Long), at alt ca. $1150 \mathrm{ft}$. Sample is from base of A zone, immediately above L zone, of the pollen profile. Coll. 1959 by D. A. Livingstone; subm. by J. Tarasmae. Comment (D.A.L.) : date is first giving minimum age for deglaciation of Cape Breton highlands (see comments for GSC333, this list). NaOH-leach omitted from sample pretreatment. Sample mixed with dead gas for counting.

\section{GSC-333. 'Silver Lake,' Nova Scotia}

$9650 \pm 150$

Lake mud from 4.25 to $4.50 \mathrm{~m}$ depth in core coll. with piston sam-

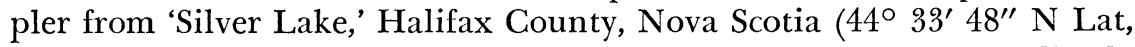
$63^{\circ} 38^{\prime} 34^{\prime \prime}$ W Long). Sample is from lower part of A zone, immediately above late-glacial L zone, of the pollen profile. Coll. 1955 by D. A. Livingstone; subm. by J. Terasmae. Comment (D.A.L.): date is first for the inferred arrival of closed forest at a mainland Nova Scotia locality; it also provides a minimum age for deglaciation. It is younger than Y-524 $(10,340 \pm 220$, Yale IV) but older than GSC-335 (9030 \pm 170 , this list) which date similar stratigraphic levels at Gillis Lake, in Cape Breton lowlands, and near Wreck Cove, in Cape Breton highlands, respectively. $\mathrm{NaOH}-$ leach omitted from sample pretreatment. Date based on one 3day count.

\section{GSC-293. Freeland, Prince Edward Island}

$640 \pm 250$

Carbonaceous body within gravel at $4.5 \mathrm{ft}$ depth in pit in beach material, E side of road, $1 \mathrm{mi} \mathrm{W}$ of Callaghan Point and 3/4 mi NNE of Freeland, Malpeque map-area, Prince Edward Island $\left(46^{\circ} 42^{\prime} 15^{\prime \prime} \mathrm{N}\right.$ Lat, $63^{\circ} 57^{\prime} 30^{\prime \prime} \mathrm{W}$ Long), at alt $25 \mathrm{ft}$. Coll. 1964 by V. K. Prest. Comment 
(V.K.P.): date indicates that organic material is burned root rather than vegetal matter deposited with beach material. $\mathrm{NaOH}$ leach omitted from sample pretreatment. Sample mixed with dead gas for counting. Date based on one 1-day count.

\section{GSC-312. St. Nazaire-de-Buckland, Quebec}

$$
12,640 \pm 190
$$

Gyttja from base of $6 \mathrm{~m}$ of organic lake sediments overlying silt and clay in a small lake $3.5 \mathrm{mi} \mathrm{NE}$ of St. Nazaire-de-Buckland, Quebec $\left(46^{\circ}\right.$ $35^{\prime} \mathrm{N}$ Lat, $70^{\circ} 36^{\prime} 30^{\prime \prime} \mathrm{W}$ Long), at alt ca $1325 \mathrm{ft}$. Sample obtained with a Livingstone piston corer. Coll. 1964 by R. J. Mott in support of glacial geology studies by N. R. Gadd. Comment (N.R.G. and J. Terasmae): lake is $\mathrm{S}$ of a moraine system extending NE from St. Philémon (Dorchester Co.) which in turn is $\mathrm{S}$ of Highland Front moraine system (Gadd, 1964); both moraine systems predate Champlain Sea. Date is minimal for deglaciation of this part of $\mathrm{N}$ slope of Appalachian Highlands; it suggests contemporaneity of an ice marginal position near St. Nazaire with pre-Champlain Sea stony marine clays in the vicinity of Trois Pistoles, Quebec (Lee, 1963), dated at 12,720 \pm 170 (GSC-102, GSC II). NaOH-leach omitted from sample pretreatment.

\section{Lake St. John series, Quebec}

\section{GSC-313. Alma}

$$
8680 \pm 140
$$

Marine shells (mostly Hiatella arctica and Macoma balthica) overlain by ca. $15 \mathrm{ft}$ sand, in a pit $1 \mathrm{mi} \mathrm{S}$ of Alma, Quebec $\left(48^{\circ} 31^{\prime} \mathrm{N}\right.$ Lat, $71^{\circ} 38^{\prime} \mathrm{W}$ Long), at alt ca. 427 ft. Coll. 1964 by P. Lasalle, Ministère des Richesses Naturelles, Québec.

\section{GSC-375. Metabetchouan}

$9340 \pm 160$ 7390 B.c.

Marine shells (mostly Macoma balthica) from gravel 3 to $4 \mathrm{ft}$ below ground surface in reworked outwash, in pit $1 \mathrm{mi} \mathrm{E}$ of Metabetchouan, Quebec $\left(48^{\circ} 26^{\prime} \mathrm{N}\right.$ Lat, $71^{\circ} 38^{\prime} \mathrm{W}$ Long), at alt ca. $398 \mathrm{ft}$. Coll. 1964 by P. Lasalle.

General Comment: shells at each site were believed to have been deposited during marine stands at or close to level at which shells occur. However, GSC-375 is from only ca. $6 \mathrm{mi} \mathrm{S}$ (ice retreated N) of GSC-313, yet it is some $600 \mathrm{yr}$ older in spite of being ca. $30 \mathrm{ft}$ lower. Perhaps the difference can be explained by the uplift that occurred during the time it took the ice to retreat $6 \mathrm{mi}$; alternatively older shells may represent a stand of the sea at some level above $427 \mathrm{ft}$ (the marine limit in the general area is at $550 \mathrm{ft}$ alt). GSC-375 provides minimum date for deglaciation, and dates show that marine invasion of the Lake St. John area occurred later than Champlain Sea episode but earlier than the Tyrrell Sea in James Bay lowlands (Lasalle, 1965). Date for GSC-313 based on one 3-day count. GSC-375 mixed with dead gas for counting. 
GSC-454. Foster Sand Pit, Ottawa, Ontario

Bones of white whale (beluga) from Foster Sand Pit, $0.5 \mathrm{mi} \mathrm{NW}$ of Uplands Airport, Ottawa, Ontario ( $45^{\circ} 20^{\prime} \mathrm{N}$ Lat, $75^{\circ} 42^{\prime} \mathrm{W}$ Long), at depth ca. $20 \mathrm{ft}$ (alt ca. $300 \mathrm{ft}$ ) in sand spit developed by shore currents of Champlain Sea (Gadd, 1963). Coll. 1956 by G. B. Rolland, Ottawa, for N. R. Gadd. Comment: dated whale bones coll. 15 to $20 \mathrm{ft}$ above shells from same pit dated as $10,700 \pm 200$ and 10,550 \pm 200 (L-604A, 604B, resp., Lamont VII). Date for collagen from bone agrees closely with dates for shells. 'Modern' date of carbonate fraction of same bone illustrates unreliability of dates for inorganic part of bone. As sample was collected since initiation of nuclear bomb testing, the greater than 'modern standard' $\mathrm{C}^{14}$ activity of the bone carbonate possibly is result of contamination with nuclear bomb carbon. If this is so, an unexpectedly rapid chemical interchange has taken place between air, groundwater, and bone in these permeable deposits above water table. Two determinations were made:

$$
\begin{aligned}
& \text { collagen fraction } \\
& \text { carbonate fraction }
\end{aligned}
$$

\section{GSC-264. Kaladar, Ontario}

Silty gyttja from base of peat and lake sediment sequence overlying sand at depth of 590 to $595 \mathrm{~cm}$ in Sharbot Creek bog, $15 \mathrm{mi} \mathrm{E}$ of Kaladar, Ontario ( $44^{\circ} 45^{\prime} 20^{\prime \prime} \mathrm{N}$ Lat, $75^{\circ} 50^{\prime} 40^{\prime \prime} \mathrm{W}$ Long). Sample obtained with 2 in. GSC piston corer. Coll. 1964 by J. Terasmae and R. J. Mott. Comment (J.T.): this date provides minimum age for deglaciation and beginning of accumulation of organic sediment. Pollen diagram from this bog indicates that sequence is truncated at the base; hence a time gap exists between gyttja and sand.

\section{GSC-270. Harrowsmith, Ontario}

$$
10,390 \pm 160
$$$$
\mathbf{8 4 4 0} \text { B.c. }
$$

Gyttja collected with Hiller sampler from base of peat and lacustrine sediment sequence in Harrowsmith bog, 2 mi WNW of Harrowsmith, Ontario, and ca. $20 \mathrm{mi}$ NW of Kingston (44 $25^{\prime} \mathrm{N}$ Lat, $76^{\circ} 42^{\prime} \mathrm{W}$ Long). Bog lies in E-trending bedrock valley within Dummer moraine. Dated gyttja is underlain by soft clay assigned to Lake Iroquois. Comment (J.T.) : date represents end of spruce episode in pollen sequence at site (which extends deeper than dated layer). Date is minimal for Lake Iroquois stage. Preliminary acid leach added to sample pretreatment, which also included cold $\mathrm{NaOH}$ leach.

\section{GSC-314. Kingston Mills, Ontario}

$10,050 \pm 390$

8100 B.c.

Small lacustrine and terrestrial molluscan shells from depth of $4 \mathrm{ft}$ in road cut through a small oriented clay ridge $3 \mathrm{mi} \mathrm{NE}$ of Kingston 
Mills, Ontario (44 $19^{\prime} \mathrm{N}$ Lat, $76^{\circ} 24^{\prime} \mathrm{W}$ Long). Sample from gently dipping slightly deformed lake clays flooring a long narrow depression between rocky ridges, alt $325 \mathrm{ft}$ (ca. $80 \mathrm{ft}$ above Lake Ontario). Coll. 1963 by E. P. Henderson. Comment (E.P.H.) : field evidence supports an interpretation of these clays as of glacial-lake origin, and the presence of terrestrial gastropods with normal lacustrine types suggests introduction of the former from nearby water-free ground. Although sample is slightly younger than was expected from information elsewhere in the Ontario basin (see Karrow et al., 1961, p. 666, "Lake Iroquois was probably drained close to 10,400 to 10,600 years ago"), it may represent a shallow, island-studded water body, the lowest and youngest of a series of short-lived, ice-dammed lakes that occupied a transition period between Lakes Iroquois and Ontario. Date is approx. same as I-1223 $(10,200 \pm 500$, unpub.) for earliest Lake Ontario from bottom of bog on $\mathrm{S}$ side of Hwy. $401 \mathrm{~W}$ of Cataraqui River, some $4.5 \mathrm{mi}$ to SW. However, the difficulty of placing an ice dam blocking the outlet of the Ontario basin compatible both with this date and with those for the Champlain Sea, ranging from $10,200 \pm 500$ (L-604D, Lamont VIII) to $11,410 \pm 150$ (GSC-187, GSC IV), suggests that present date should be treated with caution. Sample untreated and mixed with dead gas for counting.

\section{GSC-271. Scarborough, Ontario}

$38,900 \pm 1300$

Peaty layers in silt and sand of Thorncliffe Formation, exposed in Scarborough Bluffs at Cudia Park, Ontario (43 $43^{\prime} 15^{\prime \prime} \mathrm{N}$ Lat, $79^{\circ} 13^{\prime}$ $30^{\prime \prime}$ W Long). Early Wisconsinan Sunnybrook Till underlies the peaty beds and in turn overlies a thick sequence of peaty sand and clay (Scarborough Formation) dated nearby at $>52,000$ (Gro-2555; Karrow, 1962, 1964). Three tills above Thorncliffe beds are considered to be Late Wisconsinan; youngest predates Lake Iroquois dated elsewhere at ca. 12,000 yr (Karrow et al., 1961). Coll. 1964 by P. F. Karrow. Comment (P.F.K.): date supports previous assignment of Thorncliffe Formation to a midWisconsinan nonglacial interval. Date based on one 4-day count.

Note added in proof: Since preparation of this list, another sample from this deposit has yielded a much older date. Hence, the above date should be treated with caution. Details will be included in next date list.

\section{GSC-211. Tupperville, Ontario}

$11,860 \pm 170$

Plant remains from Perry Farm mastodon site 0.4 mi NE of Tupperville, Ontario $\left(42^{\circ} 35^{\prime} 30^{\prime \prime} \mathrm{N}\right.$ Lat, $82^{\circ} 16^{\prime} \mathrm{W}$ Long) from top of 4 in. of lacustrine clayey, calcareous silt (Layer c, Dreimanis, 1962, p. 248) covered by a 6 ft-thick sand bar. Coll. 1962 by A. Dreimanis, Univ. of Western Ontario, London. Comment (A.D.): this date, for plant material that grew in place, agrees with S-172 (12,000 \pm 200 ; Saskatchewan IV) for fine plant detritus from approx. same stratigraphic horizon, and confirms beginning of Early Lake St. Clair at least 12,000 yr B.P. 
Wood from uppermost part of 7 to $8 \mathrm{ft}$-thick unit of silty sand grading down into clayey silt, underlain by sand and gravel and overlain by sand, in river bank S of hwy bridge over River Aux Sables, Massey, Ontario $\left(46^{\circ} 12^{\prime} 40^{\prime \prime} \mathrm{N}\right.$ Lat, $82^{\circ} 04^{\prime} 10^{\prime \prime} \mathrm{W}$ Long). Alt at surface ca. $630 \mathrm{ft}$, hence $50 \mathrm{ft}$ above Lake Huron. Coll. 1964 by V. K. Prest. Comment (V.K.P.): dated stratum is shallow water deposit probably related to lake level ca. $50 \mathrm{ft}$ above Lake Huron, and hence may represent Algoma stage of Nipissing Great Lakes. Date based on one 3-day count.

\section{GSC-334. Sault Ste. Marie, Ontario}

$8460 \pm 140$

Gyttja coll. with Livingstone piston sampler 360 to $376 \mathrm{~cm}$ below surface of small lake (water depth ca. $1 \mathrm{~m}$ ) $4 \mathrm{mi}$ NW of Sault Ste. Marie, Ontario ( $46^{\circ} 34^{\prime} 30^{\prime \prime} \mathrm{N}$ Lat, $84^{\circ} 25^{\prime} \mathrm{W}$ Long), from base of lake sediment underlain by sand and gravel. Lake is dammed by a sand and gravel bar, alt $1025 \mathrm{ft}$, comprising highest distinct shoreline in the vicinity. Coll. 1964 by R. J. Mott for J. Terasmae. Comment (J.T.): date is somewhat younger than anticipated age of $1025-\mathrm{ft}$ shoreline. Pollen profile for site is truncated at the base, indicating a lapse of time between isolation of the lake basin and initial organic sedimentation. $\mathrm{NaOH}-$ leach omitted from sample pretreatment. Date based on one 3-day count.

\section{Chin Lake series, Ontario}

Muskeg and bog samples from test site selected for study of history and development of black spruce forest on muskeg 1.5 mi SE of Chin

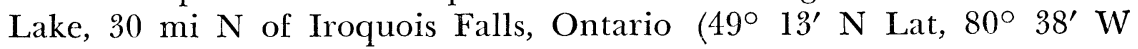
Long). Coll. 1964 by J. Terasmae.

\section{GSC-487. Chin Lake, wood}

Wood and marly gyttja coll. with piston corer from base of $1 \mathrm{ft}$ layer of lake sediment overlain by $8 \mathrm{ft}$ of peat and underlain by silty clay. Date based on one 4-day count.

GSC-309. Chin Lake, peat (bog)

$7150 \pm 140$ 5200 B.c.

Peat from base of $8 \mathrm{ft}$-deep bog, underlain by $1 \mathrm{ft}$ of lacustrine sediment; coll. with piston corer at same site as GSC-487. Date based on one 3-day count.

GSC-308. Chin Lake, peat (thick muskeg)

$5880 \pm 140$

Peat coll. with piston corer from base of $3 \mathrm{ft}$-thick muskeg cover over silty clay. A soil had developed on the clay before peat started to accumulate. 
GSC-305. Chin Lake, peat (thin muskeg)

Peat from base of $1 \mathrm{ft}$-thick muskeg cover over silty clay. A soil had developed on the clay before peat started to accumulate. Three fractions were dated:

$\begin{array}{ll}\text { untreated fraction (2-L counter) } & 270 \pm 130 \\ \text { soluble in } \mathrm{NaOH} \text { (2-L counter) } & 270 \pm 130 \\ \text { not dissolved in } \mathrm{NaOH} \text { (5-L counter) } & 220 \pm 130\end{array}$

First two dates are based on one 3-day count. Soluble fraction was mixed with dead gas for counting.

General Comment (J.T.): GSC-487 dates sediment deposited in small residual pond following drainage of Glacial Lake Barlow-Ojibway and is oldest date, so far, within basin of this glacial lake. GSC-309 is slightly older than dates for bog-bottom peat within glacial lake basin (e.g. GSC-272, $6920 \pm 140$, GSC IV; Y-223, $6960 \pm$ 90, Yale III). GSC-308 suggests that much of the muskeg expansion in the region has taken place in late postglacial time.

\section{GSC-285. Little Pic River, Ontario}

Wood chips from drainage ditch, $\mathrm{S}$ side of Trans-Canada Highway

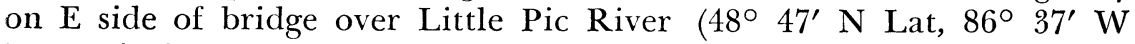
Long), in basal $1 \mathrm{ft}$ of $16 \mathrm{ft}$ of sand, with Sphaerium sulcatum in lower part, overlying silty clay with woody debris. Deposit represents a delta built into lake standing ca. $100 \mathrm{ft}$ above Lake Superior and considered to be Nipissing by Farrand (1960). Coll. 1964 by S. C. Zoltai, Ontario Dept. of Lands and Forests, Maple, Ontario, and V. K. Prest. Comment (V.K.P.): wood from the silty clay was previously dated as $5960 \pm 110$ and $5920 \pm 120$ (GSC-103 and 82, GSC II), whereas shells from overlying sand yielded date of $7060 \pm 120$ (GSC-91, GSC II). New date indicates that surface sand, as well as subsurface clay, accumulated some $6000 \mathrm{yr}$ ago (see GSC-341, this list). $\mathrm{NaOH}$ leach omitted from sample pretreatment. Sample mixed with dead gas for counting. Date based on three l-day counts.

\section{GSC-341. Little Cypress River, Ontario \\ $5130 \pm 130$}

Wood from middle layer of seven woody layers in $13 \mathrm{ft}$ sand unit overlying 3 to $4 \mathrm{ft}$ of fine sand, overlying silt, from natural gully $0.5 \mathrm{mi}$ $\mathrm{E}$ of Little Cypress River bridge on Trans-Canada Hwy, $21 \mathrm{mi} \mathrm{E}$ of Nipigon, Ontario ( $48^{\circ} 56^{\prime} \mathrm{N}$ Lat, $87^{\circ} 49^{\prime} \mathrm{W}$ Long). Coll. 1964 by S. C. Zoltai. Comment (S.C.Z.): date indicates age of lower Nipissing Great Lakes beach, at alt $692 \mathrm{ft}$ in this area (Farrand, 1960). Age is greater than generally accepted age of Nipissing Great Lakes, but is consistent with Little Pic River dates (GSC-82, $5920 \pm 120$, and GSC-103, $5960 \pm$ 110, both in GSC II; GSC-285, $6100 \pm 160$, this list). Date based on one 3-day count. 


\section{GSC-287. Rosslyn, Ontario}

$9380 \pm 150$

7430 B.C.

Wood chips 10 in. above base of 3 to $4 \mathrm{ft}$ sand unit overlying laminated clay with rare shells, from clay pits immediately SW of Rosslyn Village, $7 \mathrm{mi}$ W of Fort William, Ontario $\left(48^{\circ} 21^{\prime} 45^{\prime \prime} \mathrm{N}\right.$ Lat, $89^{\circ} 27^{\prime} 15^{\prime \prime}$ W Long), at alt $702 \mathrm{ft}$. Coll. 1964 by S. C. Zoltai. Comment (S.C.Z.): date indicates age of a post-Minong beach occurring at $743 \mathrm{ft}$ elevation in Lakehead area (Farrand, 1960; Zoltai, 1965). Sample mixed with dead gas for counting. Date based on one 3-day count.

\section{B. Western Canada}

\section{GSC-410. Grand Rapids, Manitoba}

$4670 \pm 130$

2720 B.c.

Basal peat from $5 \mathrm{ft}$-thick bog along Hwy 6, sec. 28, tp. 45, rge. 12, $\mathrm{W}$ prin. mer. (52 $53^{\prime} \mathrm{N}$ Lat, $99^{\circ} 08^{\prime} \mathrm{W}$ Long). Peat overlies gravel in a drainage ditch near southern edge of The Pas Moraine. Coll. 1965 by R. W. Klassen. Comment: sample dated in an attempt to obtain a minimum age for moraine; date believed to be considerably younger than age of moraine. Pretreatment included cold $\mathrm{NaOH}$-leach. Date based on one 3-day count.

\section{GSC-284. Duck Mountain, Manitoba}

$>37,760$

Plant detritus from fossiliferous silt $70 \mathrm{ft}$ below surface along Roaring River, sec. 30 , tp. 33 , rge. $26, \mathrm{~W}$ prin. mer. (51 ${ }^{\circ} 51^{\prime} \mathrm{N} \mathrm{Lat}, 101^{\circ} 08^{\prime}$ W Long). Silt is overlain by two tills and underlain by sand and gravel. Coll. 1964 by R. W. Klassen. Comment (R.W.K.) : studies of ostracods and mollusca from silt suggest interstadial climate, rather than interglacial as suggested by Tyrrell (1892, p. 217E). Date based on one 3-day count.

\section{GSC-346. Grandview, Manitoha}

$1670 \pm 130$

Charcoal from base of $4 \mathrm{ft}$-thick clay unit overlying till in bank of stream channel, NW $1 / 4$ sec. 33 , tp. 23 , rge. $22, \mathrm{~W}$ prin. mer. $\left(51^{\circ} 02^{\prime} \mathrm{N}\right.$ Lat, $100^{\circ} 31^{\prime} \mathrm{W}$ Long). Coll. 1963 by R. W. Klassen. Comment: in view of young date, clay is alluvial rather than a deposit of Glacial Lake Agassiz. Pretreatment included cold NaOH-leach. Sample mixed with dead gas for counting.

\section{GSC-297. Minnedosa, Manitoba}

Grass from inter-till silt exposed in $83 \mathrm{ft}$-high road cut along Minnedosa River valley, NE $1 / 4$ sec. 20 , tp. 16 , rge. 18 , W prin. mer $\left(50^{\circ} 22^{\prime} \mathrm{N}\right.$ Lat, $99^{\circ} 54^{\prime} \mathrm{W}$ Long). Silt is overlain by three tills separated by stratified sediments. Bones of a large ground squirrel (Citellus) and a large vole (Microtus), both id. by A. W. F. Banfield, Natl. Mus., Canada, were associated with the grass. Coll. 1964 by R. W. Klassen. Comment (R.W.K.): close resemblance of bones to those of Arctic ground squirrel 
(Citellus undulatus) and tundra vole (Microtus oeconomus) suggests silt is an interstadial deposit. $\mathrm{NaOH}$-leach omitted from sample pretreatment. Sample mixed with dead gas for counting.

GSC-443. Steveville Dinosaur Park, Alberta

A.D. 1590

$360 \pm 130$

Willow wood from 7 in. $\log$ at $12 \mathrm{ft}$ depth in silty floodplain of Little Sandhill Creek just above its confluence with Red Deer River, in Steveville Provincial Dinosaur Park, Alberta, SW 1/4 sec. 7, tp. 21, rge. 11, W 4th mer. (50 $46^{\prime} \mathrm{N} \mathrm{Lat,} 111^{\circ} 31.5^{\prime} \mathrm{W}$ Long), at alt ca. $2100 \mathrm{ft}$. Sample obtained from a well. Coll. 1958 by R. Fowler, High River, Alberta; subm. by A. M. Stalker. Comment (A.M.S.): date on wood believed to be in place gives indication of rate of aggradation of Little Sandhill Creek. Date based on one 3-day count.

\section{GSC-369. Lomond, Alberta}

$\mathbf{5 4 3 0} \pm \mathbf{3 2 0}$

Freshwater gastropod shells from farm dugout, ca. $2 \mathrm{mi}$ W of Lake McGregor and $11 \mathrm{mi} \mathrm{W}$ of Lomond, Alberta, SW 1/4 sec. 7, tp. 16, rge. 21, W 4th mer. ( $50^{\circ} 19.5^{\prime} \mathrm{N}$ Lat, $112^{\circ} 53.5^{\prime} \mathrm{W}$ Long), at alt ca. $3200 \mathrm{ft}$. The $11 \mathrm{ft}$-high dugout face exposes pond and slopewash deposits, with an 8 in. bed of volcanic ash $5 \mathrm{ft}$ from the base. An incipient soil ca. $1 \mathrm{ft}$ above the ash marks a halt in deposition of the pond sediments and probably represents the 'Climatic Optimum'. Shells are from upper part of volcanic ash and lower few in. of overlying pond deposits. Coll. 1964 by A. M. Stalker. Comment (A.M.S.): assuming shells are not appreciably contaminated with recycled carbon, date is minimum for deposition of ash. No pretreatment. Sample mixed with dead gas for counting.

\section{GSC-316. Drummond Valley, Alberta}

$2930 \pm 150$

Wood and organic debris from a mudflow in Drummond Valley, Alberta, tp. 36, rge. 15, W 5th mer. (51 $33^{\circ} \mathrm{N}$ Lat, $116^{\circ} 40^{\prime} \mathrm{W}$ Long), at alt ca. $6500 \mathrm{ft}$. Sample, $9.5 \mathrm{ft}$ below surface, is from lowest of several organic horizons. It is not considered to be much above bedrock, although nature of underlying deposits is unknown. Site is in mouth of valley, ca. $3 \mathrm{mi}$ from Drummond Glacier. Coll. 1964 by J. G. Nelson, Univ. of Alberta, Calgary. Subm. by A. M. Stalker. Comment (J.G.N.): date is minimum for ice retreat from area and also provides information on rate of mass wasting; i.e., 9 to $10 \mathrm{ft}$ of mudflow debris has accumulated in $3000 \mathrm{yr}$. Sample mixed with dead gas for counting.

\section{GSC-332. North Saskatchewan Crossing, Alberta}

$9330 \pm 170$

7380 B.c.

Charcoal $6 \mathrm{ft}$ below surface in river bank $300 \mathrm{ft} \mathrm{SW}$ of bridge over North Saskatchewan River, Banff National Park, Alberta $\left(51^{\circ} 58^{\prime} \mathrm{N}\right.$ Lat, $116^{\circ} 43^{\prime} \mathrm{W}$ Long), from lower part of 2 to $8 \mathrm{ft}$ section of loess containing two volcanic ash beds, overlying outwash gravel. Coll. 1964 by J. Westgate, Univ. of Alberta, Edmonton. Comment (J.W.): charcoal is be- 
lieved to have washed into the loess during or slightly later than deglaciation of this part of the valley.

GSC-197. Ruddock Creek, British Columbia

$5470 \pm 140$

3520 B.C.

Spruce $\log$ (id. by J. N. Roff, Forest Products Lab., Vancouver, B.C.) at alt $7600 \mathrm{ft}, \mathrm{W}$ of Gordenhorne Peak, head of Ruddock Creek, Monashee Range, British Columbia ( $51^{\circ} 46.5^{\prime} \mathrm{N}$ Lat, $118^{\circ} 54^{\prime} \mathrm{W}$ Long). $\log$ exposed at $\mathrm{E}$ end of small lake by artificial melting of semi-permanent snow bank during mining exploration of "E" zone of I. T. Group. No trees grow at site, and highest trees of comparable size are below alt $6700 \mathrm{ft}$. Dated tree grew at or above sample site and hence represents climate more favourable than present. Coll. 1962 by E. Dodson, Falconbridge Nickel Mines, Vancouver; subm. by W. H. Mathews, Univ. of British Columbia, Vancouver. Comment: other dated occurrences of high-level wood in southern British Columbia are GSC-169 (3760 \pm 140 , GSC III) from Downie Creek $50 \mathrm{mi} \mathrm{SE}$ and Y-140 (5850 \pm 180 , Yale II) from Mt Garibaldi $200 \mathrm{mi} \mathrm{SW}$; both were exposed by glacier retreat.

\section{Kamloops series, British Columbia}

GSC-275. Peterson Creek

$>32,700$

Wood fragments from a stream cut on Peterson Creek 3/4 mi S of Hwy 1 at Kamloops, British Columbia $\left(50^{\circ} 39^{\prime} 45^{\prime \prime}\right.$ N Lat, $120^{\circ} 19^{\prime} 40^{\prime \prime}$ $\mathrm{W}$ Long). Sample from $50 \mathrm{ft}$ below till at base of an exposure of partially oxidized, interbedded silt and sand. A second till, stratigraphically below the oxidized succession, outcrops $600 \mathrm{ft}$ to the S. Coll. 1964 by R. J. Fulton. Comment (R.J.F.): sand and silt are delta bottom-set beds deposited in a lake which occupied Thompson Valley at Kamloops at some time prior to Fraser Glaciation. Sample mixed with dead gas for counting. Date based on one 3-day count.

GSC-413. Mission Flats

Freshwater shells (Margaritifera margaritifera, Anodonta nuttalliana; id. by F. J. E. Wagner) from a borrow pit in $35 \mathrm{ft}$ of partially oxidized clayey, silty sand at base of $\mathrm{S}$ wall of Thompson River Valley ca. $5 \mathrm{mi} \mathrm{W}$ of Kamloops, British Columbia $\left(50^{\circ} 41^{\prime} 20^{\prime \prime} \mathrm{N}\right.$ Lat, $120^{\circ} 26^{\prime}$ $30^{\prime \prime} \mathrm{W}$ Long). Shells were incorporated in an alluvial fan deposit built into a lake which occupied Kamloops Lake basin prior to Fraser Glaciation. Coll. 1965 by R. J. Fulton. Comment (R.J.F.): date is minimum age for enclosing interstadial or interglacial deposits tentatively correlated lithologically with those at Peterson Creek. Date suggests that an earlier sample (GSC-79, GSC III), for which a finite age of 25,000 \pm 460 was obtained, was contaminated. Two fractions were dated after removal of the outermost $10 \%$ :

outer fraction ( $10-55 \%$ leach), one 1-day count $>35,500$

inner fraction $(56-100 \%$ leach), one 3-day count $>34,400$ 


\section{GSC-298. Otter Creek, British Columbia}

Mucky peat directly below a $2 \mathrm{~cm}$ band of volcanic ash, $85 \mathrm{~cm}$ below surface of a bog, along Hwy 5 in valley of Otter Creek, $34.2 \mathrm{mi} \mathrm{N}$ of Princeton, British Columbia (49 $53^{\prime} 00^{\prime \prime} \mathrm{N}$ Lat, $120^{\circ} 37^{\prime} 30^{\prime \prime} \mathrm{W}$ Long). Collected with Hiller peat borer. Peat from base of the $395-\mathrm{cm}$ thick bog has been dated at $9320 \pm 160$ (GSC-256, GSC IV). Coll. 1964 by R. J. Fulton. Comment (R.J.F.): date suggests the volcanic ash resulted from the Mt St. Helens eruption $3200 \mathrm{yr}$ ago (Crandell et al., 1962). Pretreatment included cold $\mathrm{NaOH}$-leach. Date based on one 3-day count.

\section{GSC-345. Pemberton Creek, British Columbia}

$\mathbf{3 4 1 0} \pm \mathbf{1 3 0}$

Charcoal and humic-rich silt from depth of $180 \mathrm{~cm}$ in Recent alluvium exposed in a natural cut on Pemberton Creek, NW of South Thompson River $1.1 \mathrm{mi}$ W of Pritchard, British Columbia (50 $41^{\prime} 25^{\prime \prime}$ $\mathrm{N}$ Lat, $119^{\circ} 50^{\prime} 50^{\prime \prime} \mathrm{W}$ Long). Charcoal was taken from lower part of a $5-\mathrm{cm}$ band of volcanic ash and top of an underlying $7.5-\mathrm{cm}$ band of humic silt. An elk horn wedge was incorporated in massive sandy silt $25 \mathrm{~cm}$ below the volcanic ash. Coll. 1963 by R. J. Fulton. Comment (R.J.F.): date is maximum for ash deposition and confirms petrologic correlation with the Mt St. Helen "Y" ash fall of 3200 B.P. (Crandell et al, 1962). It also places minimum age on the horn artifact. $\mathrm{NaOH}$ leach omitted from sample pretreatment. Date based on one 3-day count.

\section{GSC-321. Burnaby Lake, British Columbia 5390 в.c. \\ $7340 \pm 360$}

Peat from $13.5 \mathrm{ft}$ depth at Sperling Street Interchange, W end of Burnaby Lake, Vancouver, British Columbia (49 $14^{\prime} 45^{\prime \prime} \mathrm{N}$ Lat, $122^{\circ}$ $57^{\prime} 15^{\prime \prime} \mathrm{W}$ Long). Shelby tube samples reported to have contained two ash layers separated by 6 in. peat; dated peat is from finer-grained, presumably upper, side of lower ash. Both ash beds are described by R. E. Wilcox (written commun., 1963) as not significantly different from Mazama "O" pumice. Coll. 1962, subm. by W. H. Mathews, Univ. of British Columbia, Vancouver. Comment: date is older than accepted age of Mazama eruption (6600 yr B.P., Powers and Wilcox, 1964) and thus is at variance with the stratigraphic relations inferred above. Possibly the dated material came from below rather than above the ash. Pretreatment included cold $\mathrm{NaOH}-\mathrm{leach}$. Sample mixed with dead gas for counting.

\section{GSC-395. Fraser Delta, British Columbia}

$6790 \pm 150$

Marine pelecypod shells from borehole in Fraser Delta, $1000 \mathrm{ft} \mathrm{N}$ of 16th Ave., E side of 56th St., Delta Municipality, British Columbia $\left(49^{\circ} 02^{\prime} 30^{\prime \prime} \mathrm{N}\right.$ Lat, $123^{\circ} 04^{\prime} 00^{\prime \prime} \mathrm{W}$ Long), in silty sand $50 \mathrm{ft}$ below surface and ca. $45 \mathrm{ft}$ below sealevel. Coll. 1964 by W. L. Brown, Vancouver, British Columbia; subm. by J. E. Armstrong. Comment (J.E.A.): date 
represents stage in growth of Fraser Delta when Point Roberts was still an island.

GSC-396. Mitchell Island, British Columbia

Wood from borehole on Mitchell Island, Vancouver metropolitan area, British Columbia (49 $12^{\prime} 15^{\prime \prime} \mathrm{N}$ Lat, $123^{\circ} 05^{\prime} 30^{\prime \prime} \mathrm{W}$ Long), in clayey silt and silty sand $680 \mathrm{ft}$ below surface and $675 \mathrm{ft}$ below sealevel. Sampled horizon is overlain by ca. $300 \mathrm{ft}$ of fine stratified sediments capped by $170 \mathrm{ft}$ of till tentatively assigned to Surrey Drift of Vashon Stade of Fraser Glaciation. Coll. 1962 by W. L. Brown; subm. by J. E. Armstrong. Comment (J.E.A.) : dated sub-till sediments were originally assigned to Quadra sediments of Olympia Interglaciation on basis of stratigraphy. Date is older than those typical of the Olympia $(36,000 \mathrm{yr}$ and less, Armstrong et al., 1965) and deposit may represent an earlier nonglacial interval.

\section{Koksilah River series, Vancouver Island}

Peat from top and bottom of 18 -ft section of organic sandy to clayey alluvium in road cut, Island Highway SE of Koksilah River bridge near Duncan, Vancouver Island, British Columbia $\left(48^{\circ} 45^{\prime} 22^{\prime \prime} \mathrm{N}\right.$ Lat, $123^{\circ}$ $40^{\prime} 15^{\prime \prime} \mathrm{W}$ Long). Organic strata are underlain by coarse silty gravel, enclose a bed of gravel $3 \mathrm{ft}$ above base, and are overlain by discontinuous till capped by marine clay. Coll. 1964 by E. C. Halstead.

\section{GSC-318. Koksilah River upper peat}

$24,060 \pm 300$

Peat from highest exposed organic bed, $18 \mathrm{ft}$ above GSC-385.

\section{GSC-385. Koksilah River lower peat}

$\mathbf{2 4 , 3 8 0} \pm \mathbf{3 5 0}$

Peat from base of organic section at alt $50 \mathrm{ft}$.

General Comment (E.C.H.): dated unit is assigned to Quadra sediments, formed during Olympia Interglaciation. Similar deposits at Cowichan Bay $2 \mathrm{mi}$ SE yielded wood dated as $24,560 \pm 800$ (I-1225, unpub.). $\mathrm{NaOH}-\mathrm{leach}$ omitted from pretreatment of both samples.

\section{GSC-317. Marie Canyon wood, Vancouver Island 19,780 B.c.}

Wood $100 \mathrm{ft}$ above Cowichan River at Marie Canyon, Vancouver Island, British Columbia ( $48^{\circ} 46^{\prime} 43^{\prime \prime} \mathrm{N}$ Lat, $123^{\circ} 53^{\prime} 36^{\prime \prime} \mathrm{W}$ Long), from fine sand and silt within thick succession of clay, silt, and gravel beneath till. Coll. 1964 by E. C. Halstead. Comment (E.C.H.): date supports the less reliable date of $19,150 \pm 250$ (GSC-210, GSC IV) for diffuse organic matter in silt $15 \mathrm{ft}$ higher in the sub-till succession, and confirms correlation with Quadra sediments. Date based on one 3-day count.

\section{GSC-163-2. Crofton peat, Vancouver Island}

Peat at alt $100 \mathrm{ft}$ on cut bank 'behind' pulp mill $0.75 \mathrm{mi} \mathrm{N}$ of Crofton, Vancouver Island, British Columbia $\left(48^{\circ} 52^{\prime} 30^{\prime \prime} \mathrm{N}\right.$ Lat, $123^{\circ} 38^{\prime}$ 
$40^{\prime \prime} \mathrm{W}$ Long), from 4 to $6 \mathrm{in}$. bed of peaty silt and wood within $15 \mathrm{ft}$ of silt and clay underlain by sand and overlain by $10 \mathrm{ft}$ of silty sand; succession is overlain and truncated by Vashon till. Coll. 1963 by E. C. Halstead. Comment: date is based on one 4-day count in 5-L counter at 4 atm and supersedes earlier date of $>38,800$ for same sample (GSC-163, GSC III).

\section{GSC-358. Muir Point, Vancouver Island}

Peat $76 \mathrm{ft}$ above shore in coastal cliff at Muir Point near Sooke, Vancouver Island, British Columbia (48 $21^{\prime} 28^{\prime \prime} \mathrm{N}$ Lat, $123^{\circ} 44^{\prime} 48^{\prime \prime} \mathrm{W}$ Long), from uppermost of several peat beds in silt, clay, sand, and gravel underlain and overlain by till. Overlying till is tentatively assigned to last (Fraser) Glaciation. Coll. 1964 by E. C. Halstead. Comment (E.C.M. and J.G.F.): dated deposit, facing the Strait of Juan de Fuca, has not been placed in the stratigraphic sequence of Strait of Georgia-Puget Lowland to the E (Armstrong et al., 1965; Crandell, 1965), but pollen analysis (J. Terasmae) suggests it is older than Olympia Interglacial, characteristically dated as $36,000 \mathrm{yr}$ and younger (Armstrong et al., 1965).

\section{GSC-277. Denman Island shells, British Columbia}

Barnacle shells (Balanus evermanni) ca. $10 \mathrm{ft}$ above high tide on Komas Bluff, Denman Island, British Columbia $\left(49^{\circ} 35.6^{\prime} \mathrm{N}\right.$ Lat, $124^{\circ}$ 49.3' W Long), from marine stony clay in basal part of Quadra sediments. Coll. 1963 by J. G. Fyles. Comment: sample duplicates L-475A (>41,500, Lamont VII); date extends known age of clay unit of Quadra sediments (other dates GSC-207, GSC IV; GSC II; L-514C, Lamont V; L-275A, Lamont VII). Two fractions were dated in the 5-L counter at $4 \mathrm{~atm}$ :

$$
\begin{array}{ll}
\text { outer fraction }(23-59 \% \text { leach), two 1-day counts } & >47,170 \\
\text { inner fraction }(60-100 \% \text { leach), two 3-day counts } & >49,000
\end{array}
$$

Data for inner fraction permits calculation of the date as $54,200 \pm 1800$, but the corresponding infinite date is more realistic.

\section{GSC-325. Blenkinsop Lake peat, $\mathbf{3 8 4 0}$ B.c.}

Peat and organic sand coll. with Hiller sampler at depth 4.5 to $5 \mathrm{~m}$ from base of bog, Blenkinsop Lake (alt ca. $90 \mathrm{ft}$ ), Victoria, Vancouver Island, British Columbia (48 $28^{\prime} 30^{\prime \prime} \mathrm{N}$ Lat, $123^{\circ} 21^{\prime} 30^{\prime \prime} \mathrm{W}$ Long). Coll. 1964 by E. C. Halstead. Comment (E.C.H.): dated peat is underlain by clay that yielded marine shells at a nearby site dated at 12,660 \pm 160 (GSC-246, GSC IV). Sample dated to gain information on time of emergence of site, but date probably is considerably younger than emergence. NaOH-leach omitted from sample pretreatment; date based on one 3-day count. 


\section{GSC-398. Saanichton, Vancouver Island}

$12,440 \pm 230$

10,490 B.c.

Marine pelecypod shell fragments from gravel pit, Saanich Indian Reserve No. 2 near Saanichton, Vancouver Island, British Columbia $\left(48^{\circ}\right.$ $35^{\prime} 30^{\prime \prime} \mathrm{N} \mathrm{Lat}, 123^{\circ} 23^{\prime} 30^{\prime \prime} \mathrm{W}$ Long), in clay (alt $25 \mathrm{ft}$ ) at base of deltaic deposit. Clay was deposited when sealevel stood at or above top of delta (alt $60 \mathrm{ft}$ ); marine limit is at ca. $250 \mathrm{ft}$. Coll. 1964 by E. C. Halstead. Comment (E.C.H.): date applies to an intermediate stage in uplift following deglaciation.

\section{GSC-418. Patricia Bay, Vancouver Island}

$12,750 \pm 170$ 10,800 B.C.

Marine shells (Saxidomus sp.) at alt $65 \mathrm{ft}$ in gravel pit $0.5 \mathrm{mi} \mathrm{E}$ of Patricia Bay, N of airport, on Mills Crossroad, Saanich Peninsula, Vancouver Island, British Columbia (48 39 $39^{\prime \prime}$ N Lat, $123^{\circ} 26^{\prime} \mathrm{W}$ Long), from shell-rich bed in sand forming lower part of gravelly, sandy, and till-like shore deposit up to $15 \mathrm{ft}$ thick (before excavation). Beneath shore deposit are 1 to $3 \mathrm{ft}$ of marine clay over $5 \mathrm{ft}$ of till over sand. Shell bed probably represents relative sealevel approx. at top of deposit (alt ca. $80 \mathrm{ft}$ ). Coll. 1961 by E. Livingston, Water Rights Branch, Victoria, British Columbia; subm. by J. E. Armstrong. Stratigraphy revised 1963 by J. G. Fyles. Comment: date appears to apply to a somewhat higher relative sealevel and earlier stage in uplift than GSC-398 (this list). Outer $40 \%$ of shells removed before dating.

\section{GSC-389. Wellington, Vancouver Island \\ $12,740 \pm 170$ 10,790 B.c.}

Worm tubes (Serpula) at alt $230 \mathrm{ft}$ in gravel pit, N side of Island Highway $0.5 \mathrm{mi} \mathrm{E}$ of Wellington, Vancouver Island, British Columbia $\left(49^{\circ} 12.3^{\prime} \mathrm{N}\right.$ Lat, $124^{\circ} 00^{\prime} \mathrm{W}$ Long), associated with varied pelecypod shells in stony silt beneath inclined sand and gravel on flank of marine spit or bar. Crest of deposit is at alt $350 \mathrm{ft}, \mathrm{ca} .100 \mathrm{ft}$ below local marine limit. Coll. 1963 by E. C. Halstead and J. G. Fyles. Comment: date probably applies to relative sealevel at or above alt $350 \mathrm{ft}$ during an early stage in the marine inundation that followed deglaciation. Shells from a nearby site at alt $350 \mathrm{ft}$ have been dated as 12,420 \pm 150 (GSC-80, GSC II). This area has undergone greater emergence and was deglaciated slightly later than the area $50 \mathrm{mi} \mathrm{SE}$ represented by the approx. equivalent dates GSC-398, GSC-418 (this list). Date based on one 3-day count.

\section{$8680 \pm 140$ GSC-265. Willemar Bluff soil, Vancouver Island 6730 B.c.}

Organic material from paleosol $10 \mathrm{ft}$ above high tide at $\mathrm{NE}$ end of Willemar Bluff, 2 mi $\mathrm{E}$ of Comox, Vancouver Island, British Columbia $\left(49^{\circ} 40^{\prime} 20^{\prime \prime} \mathrm{N}\right.$ Lat, $124^{\circ} 53^{\prime} \mathrm{W}$ Long). Sandy soil 12 in. thick is underlain by $2 \mathrm{ft}$ of marine beach gravel over till and is capped by ca. $100 \mathrm{ft}$ of dune sand. Dunes probably formed when relative sealevel was a few ft below present. Coll. 1963 by J. G. Fyles. Comment: date agrees 
with others from surrounding region relating to relative sealevel at or below present following early post-glacial rapid uplift (S-99, $7300 \pm 120$, Saskatchewan III; $8300 \pm 200$, S-142, Capes, 1964, p. 60; GSC-229, $8290 \pm$ 140, GSC IV). NaOH-leach omitted from sample pretreatment. Date based on one 3-day count.

\section{Northern Canada, Mainland}

\section{GSC-412. Liard River, Yukon}

Wood from log in lower part of more than $100-\mathrm{ft}$ section of stratified and crossbedded sand and pebbly sand, overlain by ca. $100 \mathrm{ft}$ of boulder till, in turn overlain by $2 \mathrm{ft}$ grey-brown sand with intercalated 1/2-in. white ash bed, and capped by reddish soil, humus, and moss. Sample from actively eroding cliff, $\mathrm{E}$ side of Liard River, $39.2 \mathrm{mi} \mathrm{NW}$ of Upper Liard bridge, Alaska Hwy, Yukon Territory $\left(60^{\circ} 28^{\prime} \mathrm{N}\right.$ Lat, $129^{\circ} 41^{\prime} \mathrm{W}$ Long). Coll. 1952 by W. H. Poole. Comment (W.H.P.): preservation of wood suggests Pleistocene rather than pre-Pleistocene age, whereas highly kaolinized state of feldspar in granite pebbles within sand suggests age considerably older than latest ice advance. Feldspar in granite pebbles in till overlying sand is fresh.

\section{GSC-342. Stewart River, Yukon}

Wood enclosed in lenticular ash layer beneath 10 to $15 \mathrm{ft}$ silt, organic silt and peat in natural exposure on SE side Stewart River, at mouth of small stream ca. $8.5 \mathrm{mi}$ upstream from mouth of Valley Creek, Yukon Territory (63 $24^{\prime} \mathrm{N}$ Lat, $138^{\circ} 10^{\prime} \mathrm{W}$ Long). Coll. 1964 by O. L. Hughes. Comment (O.L.H.): as suspected from field relationships, ash is much older than surface or near-surface ash layer of central and western Yukon (Bostock, 1952; Stuiver et al., 1964).

\section{GSC-331. Mayo, Yukon}

Wood from beneath till, right bank of Stewart River $1.5 \mathrm{mi}$ downstream from Mayo, Yukon Territory (63 $36^{\prime} \mathrm{N}$ Lat, $135^{\circ} 56^{\prime} \mathrm{W}$ Long), from same locality as I (GSC)-180, (>35,000, Isotopes II). Exposure had been freshened by erosion to expose thin-bedded silt and fine-grained sand and minor gravel extending 35 to $50 \mathrm{ft}$ above river level and overlain in turn by ca. $10 \mathrm{ft}$ till and up to $50 \mathrm{ft}$ silt and sand. Abundant pieces of wood up to 5 in. diam occur near top of lower silt unit. Coll. 1964 by E. B. Owen. Comment (O. L. Hughes):till overlying wood represents last glaciation in region; it is exposed intermittently downstream, and terminates ca. $7 \mathrm{mi}$ downstream at a well-marked moraine. Despite age of sample, last glaciation may have culminated as recently as 10,500 yr ago. Sample dated in 5-L counter at $4 \mathrm{~atm}$. Date based on one 4-day count.

\section{GSC-365. Twin Buttes, Yukon}

$10,840 \pm 150$

Organic silt obtained from perennially frozen palsa bog using SIPRE-type ice-coring drill (Hughes and Terasmae, 1962). Sample was 
at 7.3 to $7.5 \mathrm{ft}$ depth, immediately above pebbly gritty silt interpreted as bog bottom. Bog is ca. $1 \mathrm{mi} \mathrm{N}$ of $\mathrm{W}$ butte at Twin Buttes, Talbot Plateau, Yukon Territory $\left(63^{\circ} 30^{\prime} \mathrm{N}\right.$ Lat, $135^{\circ} 23.5^{\prime} \mathrm{W}$ Long), and 2.5 mi SW of (beyond) the limit, as inferred from a well-defined moraine, of late Wisconsinan ice which occupied Stewart River Valley to the N. Coll. 1964 by O. L. Hughes. Comment (O.L.H.): date is minimal for deglaciation of locality. NaOH-leach omitted from sample pretreatment. Date based on one 3-day count.

\section{GSC-294. Glacier Creek, Yukon $\quad \mathbf{3 2 4 0}$ B.c.}

Basal peat coll. with SIPRE-type ice-coring drill from depth of 6.1 $\mathrm{ft}$ in bog between North Klondike River and Dempster Hwy, $1.5 \mathrm{mi} \mathrm{S}$ of bridge over Glacier Creek, Yukon Territory $\left(64^{\circ} 08.6^{\prime} \mathrm{N}\right.$ Lat, $138^{\circ} 32.5^{\prime}$ W Long). Coll. 1964 by O. L. Hughes. Comment (O.L.H.): ice advanced $\mathrm{S}$ beyond bog site almost to South Klondike River during an "intermediate" glaciation (Vernon and Hughes, in press); this event was approximately correlative with construction of moraine at Chapman Lake and hence older than 13,870 yr (GSG-296, this list). Date is minimal for deglaciation of site. Pretreatment included cold $\mathrm{NaOH}$-leach.

\section{GSC-366. Hart Lake, Yukon 2980 B.C.}

$4930 \pm 140$

Organic silt and twigs coll. from permanently frozen bog on NW side of moraine ridge impounding Hart Lake, Yukon Territory (64\% $37^{\prime}$ $\mathrm{N}$ Lat, $135^{\circ} 10^{\prime} \mathrm{W}$ Long), using SIPRE-type ice-coring drill. Sample from $13 \mathrm{ft}$ below surface in palsa mound; bog bottom not reached. Coll. 1964 by O. L. Hughes. Comment (O.L.H.): date is minimal for deglaciation of locality, which may have taken place more than 12,000 yr ago (GSC67, GSC-67-2; GSC II). NaOH-leach omitted from sample pretreatment.

\section{Chapman Lake series, Yukon}

Peat and organic silt, coll. with SIPRE-type ice-coring drill from bog on a moraine $0.4 \mathrm{mi} \mathrm{E}$ of Chapman Lake, between the lake and Dempster Hwy, Yukon Territory (64 $51.5^{\prime} \mathrm{N}$ Lat, $138^{\circ} 19^{\prime} \mathrm{W}$ Long). Moraine marks northern limit of glaciation in Blackstone River valley during an "intermediate" glacial advance (Vernon and Hughes, in press). Ice advanced to ca. $16 \mathrm{mi} \mathrm{S}$ of site during last advance recognized in the region. Coll. 1962 by O. L. Hughes.

GSC-296. Chapman Lake, basal organic silt

Basal organic silt in bog at 12.6 to $13.0 \mathrm{ft}$ depth.

$13,870 \pm 180$

11,920 B.C.

GSC-311. Chapman Lake, organic silt

$10,900 \pm 150$

8950 B.C.

Organic silt at 8.05 to $8.45 \mathrm{ft}$ depth, from base of a prominent silt layer within the bog succession. 
GSC-310. Chapman Lake, peat

Peat from 5.1 to $5.5 \mathrm{ft}$ depth, above the prominent silt layer. Pollen studies by $\mathrm{J}$. Terasmae indicate significant increases in spruce and alder pollen at ca. this level. Three determinations were made:

$\begin{array}{ll}\text { untreated fraction } & 9620 \pm 140 \\ \text { soluble in } \mathrm{NaOH} & 9510 \pm 150 \\ \text { not dissolved in NaOH } & 9620 \pm 150\end{array}$

General Comment (O.L.H.): GSC-296 (basal organic silt) provides minimum date for deglaciation of site and is compatible with the assumption, based on field evidence, that moraine is comparable in age to that at Gill Lake, Y.T. (GSC-128, 12,550 \pm 190 , GSC III). GSC-311 supports hypothesis that the prominent silt layer is loess derived from the nearby Blackstone River at beginning of last glacial advance, as it is comparable with dates of ca. 11,000 yr for Alaskan advances (Vernon and Hughes, in press); GSC-311 and GSC-310 together place this advance between 10,900 and $9600 \mathrm{yr}$ ago. $\mathrm{NaOH}$-leach omitted in the pretreatment of GSC-296, date for GSC-311 based on one 3-day count, and date on untreated fraction of GSC-310 based on one 4-day count.

\section{GSC-295. Blackstone River, Yukon \\ $6650 \pm 140$ \\ 4700 B.c.}

Silty peat from $11.4 \mathrm{ft}$ depth in boring made with SIPRE-type icecoring drill on SW edge of small pond, W of Blackstone River and 5.2 mi $\mathrm{N}$ of Chapman Lake, Yukon Territory $\left(64^{\circ} 56^{\prime} \mathrm{N}\right.$ Lat, $138^{\circ} 20^{\prime} \mathrm{W}$ Long). Pond is in subdued moraine beyond limit of and higher than moraine of "intermediate" age in vicinity of Chapman Lake. Coll. 1964 by O. L. Hughes. Comment (O.L.H.): moraine is older than that at Chapman Lake, hence older than 13,870 yr (GSC-296, this list). Pretreatment included cold $\mathrm{NaOH}$-leach. Date based on one 2-day count.

\section{GSC-372. Old Crow River, Yukon}

$6430 \pm 140$

Wood at base of $6 \mathrm{ft}$ surface peat layer overlying $100 \mathrm{ft}$ of sediments, mainly silt and clay, from riverbank exposure, Old Crow River, Yukon Territory $\left(68^{\circ} 03.5^{\prime} \mathrm{N}\right.$ Lat, $139^{\circ} 50^{\prime} \mathrm{W}$ Long). Coll. 1962 by V. N. Rampton. Comment (O. L. Hughes): the silt and clay, probably lacustrine in origin, are believed to have been deposited when Old Crow Basin was more or less completely occupied by one or more large lakes. Date is minimal for initiation of present environment of numerous lakes interspersed with bogs. Date based on one 5-day count.

\section{GSC-151-2. King Point, Yukon}

Wood and peaty fragments coll. $2 \mathrm{ft}$ above base of sea cliff $3.5 \mathrm{mi} \mathrm{E}$ of $\mathrm{E}$ end of King Point Spit, Yukon Territory $\left(69^{\circ} 04.5^{\prime} \mathrm{N}\right.$ Lat, $137^{\circ} 50^{\prime}$ $\mathrm{W}$ Long). Sample from organic silt grading up into stony clay with marine shells (thickness 10 to $18 \mathrm{ft}$ ) overlain in succession by till (20 to 
$30 \mathrm{ft}$ ), sand and silt ( 8 to $15 \mathrm{ft}$ ), and surface peat (up to $3 \mathrm{ft}$ ). The till, representing last glaciation of the site, apparently terminates in vicinity of a moraine ca. $4 \mathrm{mi} \mathrm{W}$ which is assumed to mark maximum (classical?) Wisconsin stand of Laurentide ice sheet. Coll. 1962 by O. L. Hughes. Comment: date is based on one 6-day count in 5-L counter at 4 atm and supersedes earlier date of $>38,200$ for same sample (GSC-151, GSC III), Pretreatment included cold NaOH-leach.

\section{Southern Eskimo Lakes series, Northwest Territories}

Peat from partly overgrown bluff, SW Eskimo Lakes $\left(68^{\circ} 45^{\prime} \mathrm{N}\right.$ Lat, $133^{\circ} 16^{\prime} \mathrm{W}$ Long). Coll. 1962 by O. L. Hughes.

GSC-329. S Eskimo Lakes, beneath gravel

Peat $62 \mathrm{ft}$ above lake level (sealevel) and ca. $10 \mathrm{ft}$ below top of organic silt overlain by $75 \mathrm{ft}$ glaciofluvial gravel capped by $7 \mathrm{ft}$ peat. Two determinations have been made:

$$
\begin{array}{ll}
\text { 5-L counter (standard procedure) } & >42,620 \\
\text { 5- } \mathrm{L} \text { counter (one 3-day count at } 4 \mathrm{~atm}) & >50,900
\end{array}
$$

\section{GSC-371. S Eskimo Lakes, above gravel}

Basal peat from $7 \mathrm{ft}$-thick surface peat layer overlying gravel. General Comment (O.L.H.): gravel is outwash from a glacial lobe in Sitidgi Lake basin which stood at a well-defined moraine along $\mathbf{E}$ and $\mathbf{N}$ sides of the lake during a late Wisconsinan stillstand or readvance. GSC-371 is minimal for this event, but probably is considerably younger than the outwash. Other 'basal peat' dates from region are GSC-16, $7400 \pm 200$ and GSC-25, $8200 \pm 300$ (GSC I; Mackay and Terasmae, 1963). When collected, GSC-329 was expected to date approximately beginning of outwash deposition, but subsequent study of nearby sections suggests that an unconformity separates organic silt from outwash gravel and that an ice advance occurred after deposition of silt and before deposition of gravel (J. G. Fyles, oral commun., 1965). Pretreatment of GSC-329 included cold NaOH-leach; date for GSG-371 based on one 3-day count.

\section{GSC-397. Horton River, Northwest Territories}

$3050 \pm 150$

Peat from intercalated lacustrine and peat layers exposed in crater of a pingo $50 \mathrm{ft}$ high, $11 \mathrm{mi} \mathrm{E}$ of Horton River and $65 \mathrm{mi} \mathrm{S}$ of Darnley Bay, Northwest Territories (68 $28^{\prime}$ N Lat, $123^{\circ} 16^{\prime} \mathrm{W}$ Long; Craig, 1960, p. 7), at alt ca. 1650 ft. Coll. 1959 by T. N. Irvine for B. G. Craig. Comment: NaOH-leach omitted from sample pretreatment.

\section{Bathurst Inlet series, Northwest Territories}

Marine pelecypod shells coll. on surface of sorted polygons among raised beaches, near summit of isolated hill ca. $0.5 \mathrm{mi} \mathrm{W}$ of Bathurst In- 
let, Northwest Territories $\left(66^{\circ} 42^{\prime} \mathrm{N}\right.$ Lat, $107^{\circ} 55^{\prime} \mathrm{W}$ Long), at alt ca. 465 to $475 \mathrm{ft}$. Shells dated to check on age of different species at same site. Coll. 1962 by W. Blake, Jr.

GSC-230. Bathurst Inlet, Mytilus

$8000 \pm 150$

Shell fragments of Mytilus edulis. 6050 B.C.

\section{GSC-359. Bathurst Inlet, Hiatella}

Shell fragments of Hiatella arctica.

General Comment (W.B., Jr.): the two dates agree very closely, which is of interest because Hiatella lives over a greater depth range than Mytilus. Date for GSC-359 based on one 3-day count.

\section{GSC-300. MacAlpine Moraine}

$2330 \pm 150$

Peat among boulders in pool on crest of end moraine ca. $6 \mathrm{mi} \mathrm{SW}$ of MacAlpine Lake, Northwest Territories $\left(66^{\circ} 32^{\prime} \mathrm{N}\right.$ Lat, $103^{\circ} 15^{\prime} \mathrm{W}$ Long), at alt ca. $900 \mathrm{ft}$. Peat was at lowest level that could be coll. by hand, $25 \mathrm{~cm}$ below water surface and 50 to $55 \mathrm{~cm}$ below surface of peat. Sample unfrozen but peat 5 to $10 \mathrm{~cm}$ above water level frozen (June 22nd). Coll. 1962 by W. Blake, Jr. Comment (W.B., Jr.): sample was dated in attempt to gain more information about age of this major end moraine, believed to have been forming ca. 8200 yr ago (GSC-110, $8160 \pm 110$, GSC-III; Blake, 1963), but a considerable time apparently clapsed before organic material started to accumulate (cf. GSC-116, $1090 \pm 100$, GSC III). Dates on the two fractions of peat agree within limits of error. Two fractions were dated (cf. Table 4, this list); date on soluble fraction is based on average of one 1-day count with the sample unmixed (2190 yr) and one 1-day count with the sample mixed with dead gas (2230 yr):

$$
\begin{array}{ll}
\text { soluble in } \mathrm{NaOH} & 2210 \pm 130 \\
\text { not dissolved in } \mathrm{NaOH} & 2330 \pm 150
\end{array}
$$

\section{Thelon Shell series, Northwest Territories}

Marine shells from Thelon Valley-Baker Lake area, central District of Keewatin, pertaining to deglaciation and uplift sequence in central section of Keewatin Ice Divide zone (Lee et al., 1957; Fyles, 1955). In addition to the following two dates, series includes I-1224 (6015 \pm 150$)$, Beverly Lake, alt $360 \mathrm{ft}$, to appear in a furture Isotopes date list.

\section{GSC-299. Baker Lake shells}

$$
5480 \pm 150
$$

Marine pelecypod shells (Hiatella arctica) from ground surface of fine sand and gravel, alt $295 \mathrm{ft}$, ca. $130 \mathrm{ft}$ below marine limit, $3 \mathrm{mi} \mathrm{N}$ of Baker Lake settlement, Northwest Territories $\left(64^{\circ} 31^{\prime} \mathrm{N}\right.$ Lat, $96^{\circ} 03^{\prime} \mathrm{W}$ Long). Coll. 1964 by J. A. Donaldson for B. G. Craig and J. G. Fyles. 
$5900 \pm 130$

GSC-439. Kazan River shells

3950 B.C.

Marine pelecypod shells (Hiatella arctica) from sandy ground surface, alt $250 \mathrm{ft}$, ca. $200 \mathrm{ft}$ below marine limit, $20 \mathrm{mi}$ upstream from mouth of Kazan River, Northwest Territories $\left(63^{\circ} 46^{\prime} \mathrm{N}\right.$ Lat, $95^{\circ} 40^{\prime} \mathrm{W}$ Long). Coll. 1963 by J. A. Donaldson for B. G. Craig and J. G. Fyles. General Comment (B.G.C. and J.G.F.): GSC-299 and 439 are from SE part of ice-divide zone whereas I-1224 is from Thelon Valley W (inland) from ice-divide. Together, dates indicate that remnant ice along the divide broke up more than $6000 \mathrm{yr}$ ago, permitting Hudson Bay water to penetrate $W$ through the divide zone up Thelon Valley. Deglaciation of ice divide zone was estimated earlier (Craig and Fyles, 1960, 1965) as ca. $7000 \mathrm{yr}$ B.P. based on I (GSC)-8, $6975 \pm 250$ (Isotopes I), E of ice divide ca. $100 \mathrm{mi} \mathrm{S}$ of Thelon Valley and on L-428, $5500 \pm 250$ (Lamont V; Craig, 1959) from Thelon Valley near W limit of marine inundation.

\section{GSC-289. Mistake Creek, Northwest Territories}

$6830 \pm 170$

Marine pelecypod shell from sand in bank of $8 \mathrm{ft}$ deep stream valley cut in extensive area of beaches, alt $415 \mathrm{ft}$, ca. $75 \mathrm{ft}$ below marine limit, $15 \mathrm{mi}$ NW of mouth of Mistake Creek, Roes Welcome Sound, Northwest Territories (64 $19^{\prime} \mathrm{N}$ Lat, $88^{\circ}$ 29' W Long; Craig, 1965, Fig. 2, loc 5). Coll. 1964 by B. G. Craig. Comment (B.G.C.): date is minimum for withdrawal of ice and entry of sea along this part of $W$ coast of Hudson Bay. Sample mixed with dead gas for counting.

\section{GSC-288. Ellice Hills, Northwest Territories}

$8620 \pm 140$

6670 B.c.

Shells of Mya truncata from gravelly surface of marine silt deposit, alt $624 \mathrm{ft}$, at least $75 \mathrm{ft}$ below the marine limit, $8 \mathrm{mi} \mathrm{NW}$ of Cape Weynton, W side of Committee Bay, Northwest Territories $\left(67^{\circ} 49^{\prime} \mathrm{N}\right.$ Lat, 88 $8^{\circ}$ 25' W Long; Craig, 1965, Fig. 2, loc 1). Coll. 1964 by J. A. Donaldson for B. G. Craig. Comment (B.G.C.): date is minimum for withdrawal of ice and entry of sea into central part of Committee Bay, but shells were probably deposited when Rae Isthmus was still ice covered cf. GSC-286, $6850 \pm 140 \mathrm{yr}$, this list). Date based on one 3-day count.

\section{$\begin{array}{ll}\text { GSC-286. Anigorchli Lake, Northwest Territories } & \mathbf{6 8 5 0} \pm 140\end{array}$}

Marine pelecypod shells for ground surface, alt $397 \mathrm{ft}$, ca. $65 \mathrm{ft}$ below marine limit, $20 \mathrm{mi} \mathrm{NW}$ of Repulse Bay settlement, Rae Isthmus, Northwest Territories $\left(66^{\circ} 44^{\prime}\right.$ N Lat, $86^{\circ} 42^{\prime} \mathrm{W}$ Long; Craig, 1965, Fig. 2, loc 4). Coll. 1964 by J. A. Donaldson for B. G. Craig. Comment (B.G.C.): shells are highest found in region and provide minimum date for marine connection through Rae Isthmus between Committee Bay and Repulse Bay. Date based on one 3-day count. 


\section{GSC-291. Parry Bay, Northwest Territories}

$6880 \pm 180$

Marine pelecypod shells from fine sand in $30 \mathrm{ft}$ gully cut in terrace remnant, probably deltaic, alt $441 \mathrm{ft}$, ca. $40 \mathrm{ft}$ below marine limit, $4 \mathrm{mi}$ inland and $12 \mathrm{mi}$ NW of Cape Jermain, Parry Bay, E side of Melville Peninsula, Northwest Territories (67 $52^{\prime} \mathrm{N}$ Lat, $82^{\circ} 10^{\prime} \mathrm{W}$ Long; Craig, 1965, Fig. 2, loc 3). Coll. 1964 by B. G. Craig. Comment (B.G.C.): date is minimum for retreat of ice from this area on $\mathrm{W}$ side of Foxe Basin and gives close approximation to time of formation of terrace now at $441 \mathrm{ft}$. Sample mixed with dead gas for counting.

\section{GSC-327. Erik Cove, Quebec}

$7350 \pm 150$

Shells of Mya truncata from raised marine deposits in Erik Cove, Wolstenholme, Quebec (62 $33^{\prime} \mathrm{N}$ Lat, $77^{\circ} 23^{\prime} \mathrm{W}$ Long), at alt ca. 360 ft. Coll. 1935 by D. A. Nichols. Comment: age is in accordance with date of $6900 \pm 130 \mathrm{yr}$ (NPL-58, NPL III) on marine shells coll. by B. Matthews from $271 \mathrm{ft}$ in same area.

\section{Northern Canada, Arctic Archipelago}

\section{GSC-122. Ice Ridge Moraine C, Baffin Island \\ $10,940 \pm 240$ \\ 8990 B.c.}

Microscopic organic debris from buried ice in ice-cored moraine, western margin Barnes Ice-cap, Baffin Island, Northwest Territories $\left(70^{\circ}\right.$ $00^{\prime} \mathrm{N}$ Lat, $74^{\circ} 20^{\prime} \mathrm{W}$ Long; cf. Østrem, 1964), at alt ca. $1600 \mathrm{ft}$. Coll. 1962 by G. Østrem. Comment (G. Ø.): contaminating particles, in the form of hickory chips from the picks used and plastic from the bottles in which sample was stored, were found among the organic debris; date was first thought to be based on this combination of modern hickory and infinitely old plastic. Two additional ice samples were coll. with great care in 1963, and these were processed in the field. They were believed free from contamination, but similar ages were obtained $(12,540 \pm 360$, St-1329; 11,910 \pm 140 , St-1388, Stockholm VI). It would appear now that contamination was negligible in the case of GSC-122 also, and that date does reflect age of the vegetative material. However, the windblown debris originally deposited on snowbanks (which have later been covered by morainic material) probably consists of a mixture of contemporaneous vegetation (pollen, leaf fragments, etc.) and older humified material; thus age is greater than expected. Similar results have been obtained in Scandinavia (Østrem, 1965). NaOH-leach omitted from sample pretreatment. Sample mixed with dead gas for counting. Date based on one 3-day count.

\section{GSC-390. Magda River, Baffin Island}

$6890 \pm 150$

4940 B.c.

Marine pelecypod shells from surface of delta, alt $129 \mathrm{ft}, 12 \mathrm{mi} \mathrm{E}$ of mouth of Magda River, Baffin Island, Northwest Territories $\left(71^{\circ} 39^{\prime} \mathrm{N}\right.$ 
Lat, $84^{\circ} 13^{\prime} \mathrm{W}$ Long). Coll. 1963 by B. G. Craig. Comment (B.G.C.): sample is highest collected in area, although ca. 80 to $100 \mathrm{ft}$ below marine limit. Date provides minimum for withdrawal of ice and an approximate age for $130 \mathrm{ft}$ delta. Sample mixed with dead gas for counting.

\section{GSC-307. Ivisarak Lake, Baffin Island}

$7120 \pm 140$

Marine pelecypod shells (Hiatella arctica) from surface of fine sand in probable deltaic terrace, alt $319 \mathrm{ft}, \mathrm{N}$ side, $\mathrm{W}$ end of Ivisarak Lake, Baffin Island, Northwest Territories $\left(70^{\circ} 36^{\prime} \mathrm{N}\right.$ Lat, $86^{\circ} 08^{\prime} \mathrm{W}$ Long; Craig, 1965, Fig. 2, loc 9) . Coll. 1963 by B. G. Craig. Comment (B.G.C.) : date is minimum for withdrawal of ice from area and gives approximate age of terrace now at $320 \mathrm{ft}$. Ice retreat in immediate area related to valley ice tongue phase of deglaciation. Sample mixed with dead gas for counting. Date based on one 4-day count.

\section{GSC-304. Berlinguet Inlet, Baffin Island$$
7240 \pm 150
$$

Marine pelecypod shells (Hiatella arctica) from surface of sand terrace, alt $293 \mathrm{ft}, 10 \mathrm{mi} \mathrm{SW}$ of head of Berlinguet Inlet, Baffin Island, Northwest Territories ( $70^{\circ} 55^{\prime} \mathrm{N}$ Lat, $86^{\circ} 27^{\prime} \mathrm{W}$ Long; Craig, 1965, Fig. 2, loc 7). Coll. 1963 by B. G. Craig. Comment (B.G.G.): sample lies close to marine limit and was dated to determine if postglacial in origin. Date gives age of highest marine features and is minimum for withdrawal of ice from this part of Bernier Bay-Berlinguet Inlet trough. Sample mixed with dead gas for counting.

\section{GSC-306. Agu Bay, Baffin Island}

$7690 \pm 140$

$\mathbf{5 7 4 0}$ B.c.

Marine pelecypod shells (Hiatella arctica) from frost boil a few $\mathrm{ft}$ above highest well-developed beach, alt $319 \mathrm{ft}$, central part of peninsula in Agu Bay, Baffin Island, Northwest Territories $\left(70^{\circ} 20^{\prime} \mathrm{N}\right.$ Lat, $86^{\circ} 48^{\prime}$ W Long; Craig, 1965, Fig. 2, loc 8). Coll. 1963 by B. G. Craig. Comment (B.G.C.): date gives age of highest marine features and provides minimum for withdrawal of ice from area. Sample mixed with dead gas for counting. Date based on one 4-day count.

\section{GSC-392. Cape Kater, Baffin Island}

Marine pelecypod shells (Hiatella arctica and Mya truncata) from frost boil in stony silt on top of knoll slightly above highest distinct beach, at $312 \mathrm{ft}, 13 \mathrm{mi}$ SE of Cape Kater, SW Brodeur Peninsula, Baffin Island, Northwest Territories ( $71^{\circ} 46^{\prime} \mathrm{N}$ Lat, $89^{\circ} 48^{\prime} \mathrm{W}$ Long). Coll. 1963 by B. G. Craig. Comment (B.G.C.): shells dated to confirm or deny postglacial age. Date provides minimum for withdrawal of ice and entry of sea along W coast Brodeur Peninsula (cf. GSC-241, $9280 \pm 150$, GSC IV). Date based on one 3-day count. 


\section{GSC-450. Cunningham River, Somerset Island $\quad \mathbf{8 9 9 0} \pm 140$ (whale bone) \\ $\mathbf{7 0 4 0}$ B.C.}

Part of bowhead whale (Balaena mysticetus) vertebra from eroded surface of marine silt, alt $219 \mathrm{ft}, 7 \mathrm{mi}$ inland (S) from mouth of Cunningham River, Somerset Island, Northwest Territories $\left(73^{\circ} 59^{\prime} \mathrm{N}\right.$ Lat, $93^{\circ} 40^{\prime} \mathrm{W}$ Long). Coll. 1962 by B. G. Craig. Comment (B.G.C.): this sample from same locality and $15 \mathrm{ft}$ higher than GSC-150 (9180 \pm 170 , GSC III; Craig, 1964), was dated to check accuracy of dating bone (cf. Table 3, this list). Two determinations were made, and dates on bone collagen and shells (GSC-150) agree within limits of error:

$\begin{array}{ll}\text { collagen fraction, one 3-day count } & 8990 \pm 140 \\ \text { carbonate fraction, one 3-day count } & 4990 \pm 130\end{array}$

\section{GSC-319. Aston Bay, Somerset Island}

$9380 \pm 180$

Fragments of marine pelecypod shells (Mya truncata) on ground surface of uppermost in series of beach ridges, alt 390 to $400 \mathrm{ft}$, mouth of Aston Bay, $8 \mathrm{mi} \mathrm{S}$ of Pressure Point, Somerset Island, Northwest Territories (73 $53^{\prime} 30^{\prime \prime} \mathrm{N}$ Lat, $95^{\circ} 19^{\prime} \mathrm{W}$ Long). Coll. 1964 by D. I. Smith, Univ. of Bristol, Bristol, England; subm. by B. G. Craig. Comment (B.G.C.): site lies close to marine limit and date is probably close to time of ice withdrawal from area (cf. GSC-150, $9180 \pm$ 170, GSC III; Craig, 1964). Sample mixed with dead gas for counting.

\section{GSC-378. Markham Point, Bathurst Island}

Marine pelecypod shells (Hiatella sp., Mya sp., and Astarte sp.) from ground surface less than $5 \mathrm{ft}$ above highest visible raised beaches, ca. $3 \mathrm{mi} \mathrm{N}$ of Markham Point, Bathurst Island, Northwest Territories $\left(75^{\circ} 29.5^{\prime} \mathrm{N}\right.$ Lat, $97^{\circ} 49^{\prime} \mathrm{W}$ Long), at alt ca. $345 \mathrm{ft}$. Coll. 1964 by W. Blake, Jr. and J. G. Fyles. Comment (W.B., Jr.): date suggests that highest beach represents limit of postglacial marine action, and that higher shells probably have been emplaced by glacier ice moving across a bay and incorporating shells into till (cf. GSC-166, 25,000 \pm 500; GSC-212, $35,900+1400$; GSC-223, > 28,000; GSC IV). Sample mixed with dead
-1200 ; gas for counting. Date based on one 3-day count.

\section{GSC-401. 'Muskox River', Bathurst Island}

Organic material from 2 to 8 in.thick layer whose top 2120 B.c. in. depth, overlying till, and underlying alluvium (or possibly slope deposit) along $\mathrm{S}$ bank of unnamed stream $1.5 \mathrm{mi} \mathrm{NW}$ of its junction with 'Muskox River', Bathurst Island, Northwest Territories $\left(75^{\circ} 45^{\prime} \mathrm{N}\right.$ Lat, $98^{\circ} 32^{\prime} \mathrm{W}$ Long), at alt ca. $170 \mathrm{ft}$. Coll. 1963 by W. Blake, Jr. Comment (W.B., Jr.): organic material is believed to be in place, and presence of lemming droppings suggests that climate was similar to that existing today. Sometime in the last $4100 \mathrm{yr}$ the organic debris has been 
buried, but no evidence was seen to suggest that present-day surface vegetation is being buried in same way. $\mathrm{NaOH}$-leach omitted from sample pretreatment. Date based on one 3-day count.

\section{GSC-233. 'Dartmouth Bight', Bathurst Island}

$7820 \pm 140$

Peat at 6.7 to 8.3 in. depth from hummock in depression near top of ridge, alt ca. $450 \mathrm{ft}, 1.5 \mathrm{mi} \mathrm{S}$ of 'Dartmouth Bight' and $7 \mathrm{mi} \mathrm{E}$ of Bracebridge Inlet, Bathurst Island, Northwest Territories $\left(75^{\circ} 38.5^{\prime} \mathrm{N}\right.$ Lat, $99^{\circ} 20^{\prime}$ W Long). Sample just above level at which peat was frozen in July 1963. Coll. 1963 by W. Blake, Jr. Comment (W.B., Jr.) : age of sample suggests (l) that accumulation of organic material, which began ca. 9200 yr ago (GSC-180, GSC IV; Blake, 1964) ceased shortly after 7800 yr ago, perhaps because depression became filled, or (2) that any younger material has been removed from the surface. Two fractions were dated (cf. Table 3, GSC IV), and dates on the two fractions agree within limits of error:

$$
\begin{array}{ll}
\text { soluble in } \mathrm{NaOH} & 7820 \pm 140 \\
\text { not dissolved in } \mathrm{NaOH} & 7680 \pm 140
\end{array}
$$

\section{Dundee Bight series, Bathurst Island}

Marine pelecypod shells from two localities on $\mathrm{E}$ side of Dundee Bight, Bathurst Island, Northwest Territories. Coll. 1963 by W. Blake Jr.

\section{GSC-386. Dundee Bight, east}

$\mathbf{9 0 3 0} \pm \mathbf{1 5 0}$

Shell fragments, mostly of Hiatella arctica and some of Mya truncata, from frost boils on shingle beach, E side of Dundee Bight $\left(76^{\circ}\right.$ $0.5^{\prime} \mathrm{N}$ Lat, $99^{\circ} 59^{\prime} \mathrm{W}$ Long), at alt ca. $390 \mathrm{ft}$.

\section{GSC-387. Dundee Bight, southeast}

Shell fragments of Hiatella arctica and Mya truncata from surface of delta ca. $3 \mathrm{mi} \mathrm{E}$ of head of Dundee Bight $\left(75^{\circ} 58^{\prime} \mathrm{N}\right.$ Lat, $99^{\circ} 18^{\prime} \mathrm{W}$ Long) at alt ca. $300 \mathrm{ft}$.

General Comment (W.B., Jr.): since both collections are close to marine limit in their respective areas, dates give approximate ages for highest beaches and minimum values for time of deglaciation. Dates are in accordance with a date of $9040 \pm 170 \mathrm{yr}$ (GSC-164, GSC IV; Blake, 1964) for shells at $320 \mathrm{ft}$ in Stuart River valley to NE of Dundee Bight. Both samples mixed with dead gas for counting. Each date based on one 3-day count.

\section{Tullett Point series, Prince Patrick Island}

Bones and baleen of large (bowhead) whale on and in modern icepush ridge at Tullett Point, Prince Patrick Island, Northwest Territories $\left(76^{\circ} 44^{\prime} \mathrm{N}\right.$ Lat, $121^{\circ} 10^{\prime} \mathrm{W}$ Long). Coll. 1964 by J. G. Fyles. 
GSC-355. Tullett Point, baleen

$$
1110 \pm 130
$$

Sample pretreatment includes cold $\mathrm{NaOH}$-leach; date based on one 3-day count.

\section{GSC-488. Tullett Point, whale ear}

$980 \pm 140$

Dense ear-bone ca. 4 in. across. Sample dated in two fractions: collagen fraction
carbonate fraction

\section{GSC-489. Tullett Point, whale limb}

Porous 'long bone' from whale flipper. Sample dated in two fractions; carbonate fraction mixed with dead gas for counting:
collagen fraction
carbonate fraction
$930 \pm 130$
$480 \pm 140$

General Comment: samples were dated to check accuracy of dating bone (cf. Table 3, this list). Dates for collagen fraction of dense bone and porous bone agree with each other and with date for baleen, within limits of error. As expected, date from carbonate fraction of dense bone is much closer to collagen and baleen dates than is carbonate date for porous bone.

\section{GSC-266. Ferguson Lake, Victoria Island}

$8640 \pm 140$

Rib of large whale projecting from sand at alt $370 \mathrm{ft}$, ca. $200 \mathrm{ft}$ below marine limit, $18 \mathrm{mi} \mathrm{N}$ of Ferguson Lake, Victoria Island, Northwest Territories $\left(69^{\circ} 38^{\prime} \mathrm{N}\right.$ Lat, 104 $50^{\prime} \mathrm{W}$ Long; Fyles, 1963, Fig. 1). Coll. 1959 by J. G. Fyles. Comment: date for collagen fraction is reasonable relative to somewhat older dates for marine shells closer to marine limit in this region (GSC-255, $9540 \pm 150$; GSC-269, $9400 \pm 150$; both in GSC IV). Two determinations were made:

$$
\begin{array}{ll}
\text { collagen fraction, one 3-day count } & 8640 \pm 140 \\
\text { carbonate fraction, one 3-day count } & 3260 \pm 130
\end{array}
$$

\section{GSC-367. Worth Point, Banks Island}

Willow twigs from 6 -ft bed of uncompressed moss peat at top of 100-ft coastal cliff at Worth Point, W coast of Banks Island, Northwest Territories $\left(72^{\circ} 15^{\prime} \mathrm{N}\right.$ Lat, $125^{\circ} 40^{\prime} \mathrm{W}$ Long). Peat is underlain in succession by till-like glacial or slope deposits and by interglacial pond silts. Because of uncompressed nature of dated peat bed it is inferred to postdate the latest glaciation of W part of Banks Island. Coll. 1959 by J. G. Fyles. Comment: date based on one 4 -day count in 5 -L counter at $4 \mathrm{~atm}$, and supersedes earlier date of $>38,000$ for same sample (I(GSC)-26, Isotopes I). 


\section{REFERENCES}

Date lists:

$\begin{array}{ll}\text { GSC I } & \text { Dyck and Fyles, 1962 } \\ \text { GSC II } & \text { Dyck and Fyles, 1963 } \\ \text { GSC III } & \text { Dyck and Fyles, 1964 } \\ \text { GSC IV } & \text { Dyck, Fyles, and Blake, 1965 } \\ \text { Isotopes I } & \text { Walton, Trautman, and Friend, 1961 } \\ \text { Isotopes II } & \text { Trautman and Walton, 1962 } \\ \text { Lamont V } & \text { Olson and Broecker, 1959 } \\ \text { Lamont VII } & \text { Olson and Broecker, 1961 } \\ \text { NPL III } & \text { Callow, Baker, and Hassall, 1965 } \\ \text { Saskatchewan III } & \text { McCallum and Wittenberg, 1962 } \\ \text { Saskatchewan IV } & \text { McCallum and Wittenberg, 1965 } \\ \text { Stockholm VI } & \text { Engstrand, 1965 } \\ \text { USGS II } & \text { Rubin and Suess, 1955 } \\ \text { Yale II } & \text { Preston, Person, and Deevey, 1955 } \\ \text { Yale III } & \text { Barendsen, Deevey, and Gralenski, 1957 } \\ \text { Yale IV } & \text { Deevey, Gralenski, and Hoffren, 1959 }\end{array}$

Armstrong, J. E., Crandell, D. R., Easterbrook, D. J., and Noble, J. B., 1965, Late Pleistocene stratigraphy and chronology in southwestern British Columbia and northwestern Washington: Geol. Soc. Am., Bull., v. 76, p. 321-330.

Barendsen, G. W., Deevey, E. S., and Gralenski, L. J., 1957, Yale natural radiocarbon measurements III: Science, v. 126, p. 908-919.

Berger, Rainier, Horney, A. G., and Libby, W. F., 1964, Radiocarbon dating of bone and shells from their original components: Science, v. 144, p. 999-1001.

Blake, W., Jr., 1963, Notes on glacial geology, northeastern District of Mackenzie: Canada, Geol. Survey Paper 63-28, 12 p.

1964, Preliminary account of the glacial history of Bathurst Island, Arctic Archipelago: Canada, Geol. Survey Paper 64-30, 8 p.

Bostock, H. S., 1952, Geology of northwest Shakwak Valley, Yukon Territory: Canada, Geol. Survey Memoir 267, $54 \mathrm{p}$.

Callow, W. J., Baker, M. J., and Hassall, G. I., 1965, National Physical Laboratory radiocarbon measurements III: Radiocarbon, v. 7, p. 156-161.

Capes, K. H., 1964, Contributions to the prehistory of Vancouver Island: Idaho State Univ. Mus., Occ. Papers, No. 15, 119 p.

Craig, B. G., 1959, Pingo in the Thelon Valley, Northwest Territories; radiocarbon age and historical significance of the contained organic matter: Geol. Soc. Am., Bull., v. 70, p. 509-510.

1960, Surficial geology of north-central District of Mackenzie: Canada, Geol. Survey Paper 60-18, 8 p.

1964, Surficial geology of Boothia Peninsula and King William, Somerset, and Prince of Wales Islands, District of Franklin: Canada, Geol. Survey Paper $63-44,10 \mathrm{p}$

Craig, B. G., and Fyles, J. G., 1960, Pleistocene geology of Arctic Canada: Canada, Geol. Survey Paper 60-10, 21 p.

1965, Quaternary of Arctic Canada, in Markov, F. G. et al., eds., Anthropogene Period in the Arctic and Subarctic: U.S.S.R. Research Inst. of the Geology of the Arctic, Trans., v. 143, p. 5-33 (in Russian).

Crandell, D. R., 1965, The glacial history of western Washington and Oregon, in Wright, H. E., and Frey, D. G., eds., The Quaternary of the United States: Princeton University Press, Princeton, New Jersey, p. 341-354.

Crandell, D. R., Mullineaux, D. R., Miller, R. D., and Rubin, Meyer, 1962, Pyroclastic deposits of recent age at Mount Rainier, Washington: U.S. Geol. Survey Prof Paper 450-D, p. D64-D68.

Decvey, E. S., 1958, Radiocarbon-dated pollen sequences in eastern North America, in Verhandl. der vierten Internationalen Tagung der Quartärbotaniker 1957: Veröff, Geobotanisches Institut Rübel in Zürich, Heft 34, p. 30-37.

Deevey, E. S., and Flint, R. F., 1957, Postglacial hypsithermal interval: Science, v. 125, p. $182-184$.

Deevey, E. S., Gralenski, L. J., and Hoffren, Väinö, 1959, Yale natural radiocarbon measurements IV: Am. Jour. Sci. Radioc. Supp., v. 1, p. 144-172. 
Dreimanis, Aleksis, 1962, Lake Warren and the Two Creeks Interval: Jour. Geol., v. 72 , p. $247-250$.

Dyck, Willy, and Fyles, J. G., 1962, Geological Survey of Canada radiocarbon dates I: Radiocarbon, v. 4, p. 13-26.

v. 5 , p. $39-55$

1964, Geological Survey of Canada radiocarbon dates III: Radiocarbon, v. 6 , p. $167-181$.

Dyck, Willy, Fyles, J. G., and Blake, W., Jr., 1965, Geological Survey of Canada radiocarbon dates IV: Radiocarbon, v. 7, p. 24-46.

Engstrand, L. G., 1965, Stockholm natural radiocarbon measurements VI: Radiocarbon, v. 7, p. 257-290.

Farrand, W. R., 1960, Former shorelines in western and northern Lake Superior basin: Unpub. PhD. dissertation, Univ. of Michigan, Ann Arbor, Michigan, 226 p.

Flint, R. F., and Rubin, Meyer, 1955, Radiocarbon dates of pre-Mankato events in eastern and central North America: Science, v. 121, p. 649-658.

Fyles, J. G., 1955, Pleistocene features, in Wright, G. M., Geological notes on Central District of Keewatin, Northwest Territories: Canada, Geol. Survey Paper 55-17, p. $3-4$. Franklin: Canada, Geol. Survey Bull. 101, $38 \mathrm{p}$

Gadd, N. R., 1963, Surficial geology of Ottawa map-area, Ontario and Quebec: Canada, Geol. Survey Paper 62-16, 4 p.

1964, Moraines in the Appalachian region of Quebec: Geol. Soc. Am., Bull., v. 75, p. 1249-1254.

Hughes, O. L., and Terasmae, Jaan, 1963, SIPRE ice-corer for obtaining samples from permanently frozen bogs: Arctic, v. 16, p. 270-272.

Karrow, P. F. 1962, Preliminary report on the Pleistocene geology of the Scarborough area: Ontario Dept. Mines, Prelim. Rept. 1962-1, 7 p.

1964, Pleistocene geology, Toronto-Scarborough area, in Guidebook Geology of Central Ontario: Am. Assoc. Petrol. Geol. and Soc. Econ. Paleontol. and Mineral. Meeting, Toronto, May 1964, p. 81-88.

Karrow, P. F., Clark, J. R., and Terasmae, Jaan, 1961, The age of Lake Iroquois and Lake Ontario: Jour. Geol., v. 69, p. 659-667.

Lasalle, Pierre, 1965, Radiocarbon date from Lake St. John Area, Quebec: Science, v. 149 , p. $860-862$.

Lee, H. A., 1963, Pleistocene glacial-marine relations, Trois Pistoles, Quebec: Geol. Soc. Am., Special Paper 73 , p. 195.

Lee, H. A., Craig, B. G., and Fyles, J. G., 1957, Keewatin ice divide: Geol. Soc. Am., Bull., v. 68, p. 1760-1761.

Livingstone, D. A., and Livingstone, B. G. R., 1958, Late-glacial and post-glacial vegetation from Gillis Lake in Richmond County, Cape Breton Island, Nova Scotia: Am. Jour. Sci., v. 256, p. 341-359.

Mackay, J. R., and Terasmae, Jaan, 1963, Pollen diagrams in the Mackenzie delta area, N.W.T.: Arctic, v. 16, p. 228-238.

McCallum, K. J., and Wittenberg, J., 1962, University of Saskatchewan radiocarbon dates III: Radiocarbon, v. 4, p. 71-80.

1965, University of Saskatchewan radiocarbon dates IV: Radiocarbon, v. 7 , p. $229-235$

Neale, E. R. W., 1964, Cape North, Nova Scotia: Canada, Geol. Survey Map 1150A.

Olson, E. A., and Broecker, W. S., 1959, Lamont natural radiocarbon measurements V: Am. Jour. Sci. Radioc. Supp., v. 1, p. 1-28.

p. $141-175$.

Østrem, Gunnar, 1964, Ice-cored moraines in Scandinavia: Geografiska Annaler, v. 46, p. $282-337$

p. 1-38. 1965 , Problems of dating ice-cored moraines: Geografiska Annaler, v. 47A

Powers, H. A., and Wilcox, R. E., 1964, Volcanic ash from Mt. Mazama (Crater Lake) and from Glacier Peak: Science, v. 144, p. 1334-1336.

Preston, R. S., Person, Elaine, and Deevey, E. S., 1955, Yale natural radiocarbon measurements II: Science, v. 122, p. 954-960. 
Rubin, Meyer, and Suess, H. E., 1955, U.S. Geological Survey radiocarbon dates II: Science, v. 121, p. 481-488.

Stuiver, Minze, Borns, H. W., Jr., and Denton, G. H., 1964, Age of a widespread laver of volcanic ash in the southwestern Yukon Territory: Arctic, v. 17, p. 259-261. Trautman, M. A., and Walton, Alan, 1962, Isotopes, Inc. radiocarbon measurements II: Radiocarbon, v. 4, p. 35-42.

Tyrrell, J. B., 1892, Report on northwestern Manitoba with portions of the adjacent districts of Assiniboia and Saskatchewan: Canada, Geol. Survey Ann. Rept., v. 5, 1890-9l, pt. 1, Rept. E, 235 p.

Vernon, Peter, and Hughes, O. L., in press, Surficial geology of Dawson, Larson Creek, and Nash Creek map-areas, Yukon Territory: Canada, Geol. Survey Bull. 136.

Walton, Alan, Trautman, M. A., and Friend, J. P., 1961, Isotopes, Inc. radiocarbon measurements I: Radiocarbon, v. 3, p. 47-59.

Zoltai, S. C., 1965, Glacial features of the Quetico-Nipigon Area, Ontario: Canadian Jour. Earth Sci., v. 2, p. 247-269. 